\title{
Iron availability as a dominant control on the primary composition and diagenetic overprint of organic-matter-rich rocks
}

Nicolas Tribovillard ${ }^{\mathrm{a}, *}$, Ebraheem Hatem ${ }^{\mathrm{a}}$, Olivier Averbuch ${ }^{\mathrm{a}}$, Florent Barbecot ${ }^{\mathrm{b}}$, Viviane Bout-Roumazeilles ${ }^{\text {a }}$, Alain Trentesaux ${ }^{\text {a }}$

${ }^{a}$ Université Lille 1 \& CNRS UMR LOG 8187, Bâtiment SN5, 59655 Villeneuve d'Ascq Cedex, France

${ }^{\mathrm{b}}$ GEOTOP_-Université du Québec à Montreal, Montréal, Canada

Corresponding author. E-mail address: Nicolas.Tribovillard@univ-lille1.fr (N. Tribovillard).

Keywords: Geochemistry - Organic matter preservation - Iron shuttle - Arsenic Molybdenum - Antimony

\begin{abstract}
Iron is known to stimulate surface ocean productivity, as well as intervene with bacterially-mediated processes of organic matter remineralization, during early diagenesis. In this paper, we examine the influence of iron supply on the geochemistry (trace metals, $\delta^{34} \mathrm{~S}$, organic matter) of sedimentary rocks deposited in a clastic-dominated marine ramp environment. To this end, we studied two Late Jurassic formations of the Boulonnais area (North- France). Both formations were deposited under quite similar conditions, but they differ in the reactive-iron supply they received. Only one of the two formations was affected by the particulate iron shuttle process. Our results indicate that 1) the iron shuttle may be recorded through concomitant enrichments in $\mathrm{P}, \mathrm{Mo}, \mathrm{As}$ and $\mathrm{Sb} ; 2$ ) a limited reactive-iron supply will allow the sulfurization of organic matter, even in a context of moderate productivity. Thus sulfurization can be a factor favoring a noticeable accumulation of organic matter: iron may thus be an important agent in the $\mathrm{C}$ cycle.
\end{abstract}

\section{Introduction}

The geological rocks of the Late Jurassic times (Kimmeridgian- Tithonian), cropping out along the Boulonnais shore (Strait of Dover, Northern France; Fig. 1), represent a 
proximal, lateral equivalent of the Kimmeridge Clay Formation (when used with a proper name, the word Formation will be abbreviated as Fm.), famous as a major petroleum source rock. These formations accumulated in a clastic dominated ramp environment where the sedimentary succession is made up of an alternation of marlstone-dominated formations (called "Argiles") and sandstone-dominated formations (termed "Grès") reflecting a range of water depths from lower offshore to shoreface settings, respectively (e.g., Wignall, 1991; Ramanampisoa et al., 1992; Proust et al., 1995; Deconinck et al., 1996; Wignall and Newton, 2001; Williams et al., 2001; Al-Ramadan et al., 2005). In the present paper we compare two formations, namely the Argiles de Châtillon Fm. And the Bancs Jumeaux Fm. that accumulated in similar conditions: a relatively rapidly rising sea level (Taylor et al., 2001; Williams et al., 2001) and "normal" marine productivity in the sense that it was calculated that surface-water productivity was in the range of present-day open shelves (Tribovillard et al., 2001). Both formations show a comparable marly facies with relatively abundant marine organic matter (OM), but they also yield marked differences. Horizons within the Argiles de Châtillon Fm. contain abundant OM that is rich in sulfur (sulfurized OM), whereas the Bancs Jumeaux Fm. does not yield such S-rich OM, but is instead rich in phosphatized biogenic clasts, typically bivalve shells. The two formations show contrasting magnetic parameters. In this paper, we further explore the differences between these formations, notably through the examination of the trace-metal and $\mathrm{S}$ isotope composition, and emphasize the role played during authigenesis/diagenesis. Our focus is on determining whether reactive-iron availability could be an important factor controlling OM storage.

\section{Geological framework and previous results}

The shoreface sandstones and offshore mudrocks of the Kimmeridgian-Tithonian times are located along the Boulonnais coast of the Dover Strait (Fig. 1) and were deposited on the northwest European epicratonic platform, forming an embayment into the shoreline. The mudstones and shales of the Argiles de Châtillon (autissiodorensis + gigas-elegans ammonite zones, straddling the Kimmeridgian-Tithonian boundary), and the transition between the Argiles de la Crèche Fm. and Argiles de Wimereux Fm. (the so-called Bancs Jumeaux Fm., wheatleyensis + pectinatus ammonite zones, Tithonian) represent a low-energy shelf facies deposited below fair-weather wave base, but with some storm influence expressed as thin shelly limestone interbeds and coquina beds (Wignall, 1991; Proust et al., 1995; Deconinck et al., 1996; Wignall and Newton, 2001; 
Williams et al., 2001). Similar to the more distal, time-equivalent, shales and mudstones of the Kimmeridge Clay Fm., exposed on the Dorset (UK) coast, these sediments are also organic-rich (Tribovillard et al., 2001). Detailed descriptions of the lithofacies and stratigraphy (including sequence stratigraphy) can be found in Proust (1994), Proust et al. (1993, 1995), Herbin et al. (1995); Deconinck et al. (1996); Wignall (1991); Wignall and Newton (2001); Williams et al. (2001), Al-Ramadan et al. (2005) and Braaksma et al. (2006).

\subsection{The Argiles de Châtillon Formation}

The Argiles de Châtillon Formation is well exposed at the Cap de la Crèche (Crèche Cape), between Wimereux and Boulogne, where its thickness is about $30 \mathrm{~m}$. The formation consists of claystone and marlstone (referred to mudstones in what follows) accumulations with some intervals of laminated black shales and a laterally variable number of coquina beds (tempestites made of accumulations of Nanogyra shell beds; Fürsich and Oschmann, 1986). These storm beds are numerous at the Kimmeridgian-Tithonian boundary. In contrast to the mudstones, the laminated, small pyrite framboid-rich, organic-rich, black shales with an impoverished benthic fauna is a facies also typical of the Kimmeridge Clay Fm. classically interpreted as deposited under oxygen-restricted conditions (Wignall and Newton, 2001). Within the Argiles de Châtillon Fm., the clay mineral assemblage is very homogeneous, being made of illite $(>50 \%)$, kaolinite (ca. 30\%), smectite + illite/ smectite mixed layers $(<20 \%)$, plus b 10\% chlorite (Proust et al., 1995; Deconinck et al., 1996). At the uppermost part of the formation, the assemblage evolves towards dominating smectite + illite/smectite mixed layers $(>70 \%)$.

\subsection{The Bancs Jumeaux Fm.}

The Bancs Jumeaux Fm. is located at the boundary between the Argiles de la Crèche Fm. and the Argiles de Wimereux Fm. This interval (about 1.20mthick) is sometimes referred to as the La Rochette Nodule Beds or the Bancs Jumeaux Fm. (Proust et al., 1995; Williams et al., 2001). It is bound at its base and top by two sharp erosional surfaces overlain by accumulations of phosphatic fossils and nodules, and quartz pebbles. Both levels correspond to condensed sedimentation plus erosion. These lower and upper P-rich levels are named P1 and P2, respectively. The top of the Argiles de la Crèche Fm. (i.e., the P1 horizon) is dated as belonging to the wheatleyensis zone, and the base of the Argiles de Wimereux Fm. (P2 
horizon) to the Pallasioides zone (Geyssant et al., 1993; Herbin et al., 1995). The pectinatus zone has been recently documented in the upper part of the Bancs Jumeaux Fm. (Williams et al., 2001). At Wimereux, the Bancs Jumeaux Fm. consists of marlstones with three intercalated micritic mudstones containing occasional reworked thin pelecypod shell horizons. Only two of these beds are present at the Cap de la Crèche. These carbonate beds are interpreted as being of diagenetic origin (Tribovillard et al., 2012a). The marlstones of the Bancs Jumeaux Fm. do not show strong sedimentological evidences of condensed sedimentation, contrary to the P1 and P2 levels that bound the formation. However, reduced sedimentation rates are possibly shown by the presence of scattered glauconite grains. The Bancs Jumeaux Fm. has been interpreted as a transgressive systems tract (Proust et al., 1995; Deconinck et al., 1996; Williams et al., 2001). The Bancs Jumeaux Fm. is placed within the general evolution observed between the uppermost Argiles de la Crèche Fm. and lowermost Argiles de Wimereux Fm., with an increase in the illite + kaolinite abundance (from 30 to $50 \%$, and 15 to $30 \%$, respectively) at the expense of illite smectite mixed-layers + smectite (from 50 to $15 \%$; Proust et al., 1995).

\subsection{Organic matter}

Both formations contain sedimentary organic matter $(\mathrm{OM})$; the total organic content (TOC, in weight \%) is higher in the Argiles de Châtillon than in the Bancs Jumeaux. Rock Eval data for the studied two formations are compared in Table 1. See Espitalié (1993) for the meaning and interpretations of the Rock Eval-pyrolysis parameters.

\subsection{The organic content of the Argiles de Châtillon Fm.}

The organic content of the Argiles de Châtillon Fm. is dominated by amorphous organic matter (AOM; Tyson, 1995). AOM represents the part of the kerogens, the origin and nature of which cannot be determined through palynofacies observation alone (Tyson, 1995). Here, AOM is itself dominated by two main varieties distinguished by their colors: orange or brown (see description and microphotographs in Tribovillard et al., 2001). Orange AOM exhibits distinct (and in some cases, almost angular) edges, and has a gel-like texture. Brown AOM has a more heterogeneous "flock" texture, less distinct "fuzzy" outlines, and tends to be less lustrous; in untreated kerogen slides it exhibits a more granular texture and the presence of pyrite crystallites and tiny framboids. It is also associated with lower fluorescence 
intensities. In previous studies on the Kimmeridge Clay, orange AOM has been found to be nanoscopically amorphous, while brown AOM shows an ultralamina ultrastructure which is thought to represent selectively preserved cell walls of microplankton (Boussafir et al., 1994, 1995a, 1995b; Gelin et al., 1995, 1999). The ratio of the two types of AOM changes with the TOC of the sediments, the proportion of orange AOM increases rapidly as TOC increases from 2 to 7\% (Bialkowski et al., 2000; Tribovillard et al., 2001). The orange AOM is interpreted as resulting from natural vulcanization or sulfurization (reaction with sulfides and polysulfide, see below), whereas brown AOM is interpreted to result from selective preservation of resistant biopolymers (selective oxidation of metabolizable constituents; Boussafir et al., 1994, 1995a, 1995b; Largeau et al., 1990; Derenne et al., 1991). Natural sulfurization is an early diagenetic process leading to the inter- or intramolecular incorporation of reduced inorganic sulfur species into low-molecular-weight functionalized lipids resulting in the formation of resistant high molecular weight abiogenic "geopolymers" (Tegelaar et al., 1989).

\subsubsection{The Bancs Jumeaux Formation}

The Bancs Jumeaux Formation has TOC values $\leq 2 \%$ (Table 1); the organic content is largely dominated by brown AOM. For both formations, the palynofacies also contain minor amounts of gelified and black opaque terrestrial debris, together with algal debris and algae (Tribovillard et al., 2004a).

\subsection{Magnetic parameters and initial consideration about the role of iron}

Various magnetic parameters, namely, magnetic susceptibility (MS), sIRM and S ratio, were measured for the Argiles de Châtillon Fm. (Tribovillard et al., 2002) and the Bancs Jumeaux Fm. (Tribovillard et al., 2004a). The results indicate that the MS signal of the rocks of these formations was governed by the clay-mineral content, but also tuned to the variable presence of iron sulfides. This second factor was linked to the type of AOM present, either orange (sulfurized) or brown (non-sulfurized). The initial interpretation was that the type of AOM (orange vs. brown) resulted from the reaction of sulfide ions with organic molecules during the sulfate-reduction stage of OM diagenesis. If sufficient reactive iron (defined as iron phases that readily react with hydrogen sulfide; Poulton and Raiswell, 2002) was available to fully buffer the sulfide ions formation, iron sulfides could form in abundance (which impacted 
the MS of the sediments) and sulfide ions could not react with OM (no sulfurization, hence the presence of brown AOM). Conversely, if reactive iron did not immobilize all the sulfide ions formed by sulfate-reduction, part of the sulfide ion pool could react with OM, inducing the formation of orange AOM but blurring the relationship between OM abundance and MS signal. In this scenario (Tribovillard et al., 2001, 2004a), iron plays a central role, in that its abundance, compared to that of sulfide ions, will control OM early diagenesis and lead to the formation of either brown or orange AOM. However, in this scenario, the emphasis was not set on the variations in the reactive-iron supply but instead on the amount (or flux) of OM subject to sulfate reduction (i.e., surface productivity) and on the reactivity of OM (e.g., its nature more or less labile, hence its propensity to undergo sulfate reduction). In the present paper, the emphasis is placed on the fluctuation of the reactive-iron supply and its impact, upon trace metal and S stable isotope content in the rocks.

\section{Iron and the particulate shuttle effect}

Iron has been the focal point of many studies about sediment geochemistry, notably regarding authigenesis and early diagenesis of sediments deposited under reducing conditions. Such conditions are propitious to the formation of iron sulfides and they involve OM. Within the huge literature, see notably the seminal papers of Berner $(1970,1984)$ as well as recent syntheses about iron written by Raiswell and Canfield (2012) and Rickard (2012) or edited by Taylor and Konhauser (2011); (see more specifically Poulton and Canfield, 2011; Taylor and Macquaker, 2011). For this kind of study, it is important to distinguish between the part of reactive iron that can be involved in chemical reactions, and "inert" iron (firmly bound within crystal lattices) that is poorly or not reactive during sediment early diagenesis (e.g., Canfield et al., 1992, 1996). To this end, numerous works were dedicated to iron speciation, with a recent, renewed approach (Wijsman et al., 2001; Poulton and Raiswell, 2002; Poulton and Canfield, 2005; Lyons and Severmann, 2006; Raiswell and Canfield, 2012), to selectively extract and distinguish between mineralogical forms of the iron-carrying phases of sediments and sedimentary rocks. In the present work, taking into consideration the long diagenetic history of the sediments deposited about 152 millions years ago, as well as the shaly nature of the studied sedimentary rocks, we considered that the chemically-inert fraction of the iron content was the part incorporated into the lattices of alumino-silicates; the relative amount of this non-reactive, or detrital, iron is calculated according to the following formula:

$F e_{\text {detrital }}=[\mathrm{Al}]_{\text {sample }} x[\mathrm{Fe}] /[\mathrm{Al}]_{\text {upper crust }}$, with $[\mathrm{Fe}] /[\mathrm{Al}]_{\text {upper crust }}=0.44$ 
(McLennan, 2001).

The iron content in excess to the detrital part is then derived using the formula:

$F_{\text {exs }}=F e_{\text {total }}-F e_{\text {detrital }}$

We consider that this $\mathrm{F}_{\text {exs }}$ fraction provides a good estimate of the initial reactive iron proportion during deposition of its mineralogical carrier phase, after the successive steps of long-term diagenesis (see Scholz et al., 2014).

In addition, a series of recent studies focused upon the so-called particulate shuttle effect (Crusius et al., 1996; Algeo and Lyons, 2006; Chappaz et al., 2008; Goldberg et al., 2009; Dellwig et al., 2010; Owens et al., 2012; Scott and Lyons, 2012; Jilbert and Slomp, 2013; Scholz et al., 2013). In a few words, the oxy-hydroxides of Fe and Mn easily bind to dissolved chemical species present in the oxidizing part of the water column. During settling, Fe- and Mn-oxy-hydroxides can thus adsorb significant amounts of Mo (Crusius et al., 1996; Chappaz et al., 2008; Algeo and Tribovillard, 2009; Helz et al., 2011; Kashiwabara et al., 2011; Martin et al., 2013) and iron oxy-hydroxides can incorporate P and As (see Section 6.3). The oxy-hydroxides in turn bind to settling particles or flocs of OM, or stick onto clay minerals. Once deposited, they can be chemically reduced and thus can release the ions they scavenged. These ions can in turn get solubilized at the sediment-water interface or into pore waters. In the latter case, they can be incorporated into diagenetic mineral phases (sulfides, carbonates, silicates, etc.; see Section 6.3). Emphasis is usually set on the role of iron in the particulate shuttle, but the phenomenon may also be important for manganese (März et al., 2011a).

In addition, the iron shuttle process may be enhanced where iron supply is itself enhanced. In particular, such enhancements may be observed in two contexts: 1) Dissolution of reactive iron from sediments under suboxic conditions, followed by transport to oxic parts of the water column and Fe oxy-hydroxidesre-precipitation. Such a situation requires the presence of an oxygen minimum zone impinging on the continental margin above the depositional setting studied. In addition, redox conditions cannot be too severely reducing, as otherwise the diagenetically released iron will be fixed in situ as iron sulfides, preventing its diffusion back into the water column. 2) Under fully oxic conditions, purely physical processes can cause re-suspension of fine Fe oxyhydroxides particles at the sea floor (e.g., through wave and/or current activity on a continental shelf), and re-depositional deeper on the continental slope. These points are discussed below. 
The Bancs Jumeaux Fm. has been much studied recently and the depositional conditions are rather well constrained (Tribovillard et al., 2004a, 2008a, 2012a, 2012b). Notably, the sediments of the formation are interpreted as deposited under normally oxygenated, marine conditions prone to the operating of the iron particulate shuttle (Tribovillard et al., 2012b). The iron shuttle hypothesis explains why the Bancs Jumeaux sediments are enriched in Mo and not in $U$ as visualized in a Mo vs. $U$ diagram as defined in Algeo and Tribovillard (2009).

\section{Methods}

\subsection{Sampling}

For the Bancs Jumeaux Fm., we studied 16 samples from the outcrop at the North end of Wimereux, at the so-called Pointe de la Rochette. The sampling step was $10 \mathrm{~cm}$. The geochemical composition (organic and inorganic data) has been partly published in Tribovillard et al. (2011, 2012a, 2012b). Here, additional results are given regarding trace metal, $\mathrm{P}$ and $\mathrm{Fe}$ contents.

For the Argiles de Châtillon Fm., the samples were picked from the outcrop of the socalled Cap de la Crèche. The initial study of 2001 (Tribovillard et al., 2001) was grounded on the examination of the organic content of 55 samples. Twenty-one samples were also analyzed for major element concentrations but the results had not been published yet. In this study, we used the same set of 55 samples plus an additional 22 samples spanning the wide range of $\mathrm{OM}$ content of this formation. We only sampled organic-rich facies and organicpoorer mudstones at the exclusion of the other facies encountered in the Argiles de Châtillon Fm., namely, coquina beds (= tempestites made of Nanogyra shell accumulation) and some carbonate/sandstone beds, because these other facies represent other deposition conditions. The rationale for the sampling was to consider only facies of the same type (fine-grained, clastic-dominated mudstones and shales) but covering a large range of organic content, because one of the goals of the paper is to study factors favoring OM preservation and accumulation. Thus we studied samples containing abundant OM dominated by orange AOM, or dominant brown AOM and samples yielding a medium to low organic content. For this second sample set, major and trace element contents were determined. Lastly, some additional analyses (sample set \#3) were collected from Ramdani (1996). 


\subsection{Analytical procedures}

The carbonate content was determined with a Bernard-type calcimeter (acid digestion followed by $\mathrm{CO} 2$ volume determination; accuracy $<5 \%$ ). The mineralogical nature of the carbonate was determined following usual X-ray diffraction (XRD) procedures on micropulverized samples. Concerning the determination of clay mineral assemblages, in addition to the results published by Deconinck et al. (1996) for the entire late Jurassic of the Boulonnais, we analyzed the samples chosen for geochemical analysis. The clay fraction was isolated and analyzed using the standard protocol for clay-mineral assemblage determination (XRD analyses of both carbonates and clays was performed using a Bruker D4 Endeavour apparatus together with the Macdiff software; see detailed protocols in Bout-Roumazeilles et al., 1999).

We observed and analyzed three phosphatized shells and their infilling, as well as ten indurated marlstone fragments (Bancs Jumeaux Fm.) using a FEI Quanta 200 scanning electronic microscope equipped with a Rontec energy-dispersive-spectroscopy (EDS) microprobe, looking for $\mathrm{P}$ concentrations.

For the analysis of the second sample set of the Argiles de Châtillon Fm., the determination of the major- and trace-element contents was carried out by ICP-OES and ICPMS by the spectrochemical laboratory of the Centre de Recherches en Pétrographie et Géochimie of Vandoeuvre-les- Nancy (geochemistry laboratory of the French Centre National de la Recherche Scientifique). The samples were prepared by fusion with $\mathrm{LiBO}_{2}$ and $\mathrm{HNO}_{3}$ dissolution. Precision and accuracy were both better than $1 \%$ (mean $0.5 \%$ ) for major-minor elements and $5 \%$ for trace metals, as checked by international standards and analysis of replicate samples (Carignan et al., 2001). Enrichment factors (EFs) were calculated as: $\mathrm{X}_{\mathrm{EF}}=$ $\left[(\mathrm{X} / \mathrm{Al})_{\text {sample }} /(\mathrm{X} / \mathrm{Al})_{\text {PAAS }}\right]$, where $\mathrm{X}$ and $\mathrm{Al}$ represent the weight $\%$ concentrations of elements $\mathrm{X}$ and $\mathrm{Al}$, respectively. Samples were normalized using the post-Archean average shale (PAAS) compositions of Taylor and McLennan (1985). Aluminum normalization is commonly used to minimize the effects of variable dilution by carbonate or biogenic silica, although certain caveats apply to this approach (for a discussion, see Van der Weijden, 2002). The convenience of using enrichment factors is that any value larger than 1.0 points to enrichment of an element is relative to its average crustal abundance. In practical terms, EFs $>3$ represent a detectable enrichment of an element over average crustal concentrations, and EFs $>10$ represent a moderate to strong degree of enrichment (Algeo and Tribovillard, 2009). 
Pyrite is commonly observed in both studied sections. We analyzed the S isotopic composition of pyrite that is present as framboids or tiny crystals included within or associated with OM, notably AOM. Isolating small pyrite crystallites from OM and AOM is quite challenging. Consequently, determining the $\mathrm{S}$ isotopic composition of these small pyrite grains is facing the difficulty that the isotopic signature would be impacted by the presence of organically-bound S. Thus, we focused upon the larger pyrite particulates (see poly-framboids in Fig. 5) that can easily be extracted from the sediments. For such large pyrite extraction, 11 samples of the Bancs Jumeaux and 6 samples of the Argiles de Châtillon were crushed to centimeter-size lumps that were decarbonated using $\mathrm{HCl}$. Once deflocculated after several rinsings, the suspended clay minerals were removed from the beakers by removing the supernatant (the operation must be repeated several times). The residue was then treated with HF to solubilize quartz grains and residual aluminosilicate grains. After these operations, only clean pyrite particles and some heavy minerals were still present. To determine the sulfur isotope composition $\left(\delta^{34} \mathrm{~S}\right)$, the pyrite samples were oxidized with $\mathrm{O}_{2}$ at $1050{ }^{\circ} \mathrm{C}$ to produce $\mathrm{SO}_{2}$ that was analyzed using a VG Sira mass spectrometer (Institute of Earth Sciences, Paris XI-Orsay University). The results were expressed in $\delta$ conventional notation, relative to the standard V-CDT (Vienna Canon Diablo Troilite). The standard used is a $\mathrm{Ag}_{2} \mathrm{~S}$ MERCK with $\delta^{34} \mathrm{~S}=+3 \%$ vs. V-CDT. Each sample was measured in duplicate and the average values are reported. The analytical precision of measurements is $\pm 0.3 \%$; the reproducibility is of $\pm 1 \%$.

\section{Results}

From a facies point of view, the two formations are quite similar, showing rocks made of a mixture of dominating silt and clays from one part, and biogenic carbonate from the other part, with $\mathrm{CaCO}_{3}$ concentrations ranging between $10 \%$ and $31 \%$ for the Argiles de Châtillon and between $18 \%$ and $50 \%$ for the Bancs Jumeaux, excluding the diagenetic carbonate beds $>90 \% \mathrm{CaCO}$. The clay mineral assemblages are somewhat different in that the samples of the Argiles de Châtillon Fm. are dominated by illite+kaolinite, whereas those of the Bancs Jumeaux Fm. are richer in smectite (Table 2).

The major/minor/trace-element concentrations determined for the Argiles de Châtillon samples are reported in Tables 3 and 4. For major/ minor elements, the Al-normalized distribution is quite smooth, except for $\mathrm{Ca} / \mathrm{Al}$ that depends on the amount of calcium carbonate present in the rock, and $\mathrm{Si} / \mathrm{Al}$ that is linked to variable proportions of silt-sized quartz particles (Table 5). 
For trace elements, chromium, germanium, nickel, lead, thorium, and vanadium $(\mathrm{Cr}$, $\mathrm{Ge}, \mathrm{Ni}, \mathrm{Pb}$, Th and $\mathrm{V}$, respectively) show linear correlations to the $\mathrm{Al}$ content with even a determination coefficient $\mathrm{R}^{2}$ equal to 0.83 in the case of $\mathrm{V}$, a trace metal reputed to be redoxsensitive (Table 6). In contrast, molybdenum, arsenic and antimony, uranium, zinc and zirconium (Mo, As, $\mathrm{Sb}, \mathrm{Zn}$, and $\mathrm{Zr}$, respectively) show poor correlation with Al. Uranium is in an intermediate position (Table 6). Considering enrichment factors (EFs; Table 5), $\mathrm{V}, \mathrm{Cr}$, $\mathrm{Ni}, \mathrm{Cu}, \mathrm{Zn}, \mathrm{Zr}, \mathrm{U}$, and Th show enrichment factors close to the value 1, which means that the elements are present in proportions identical to the average upper crust with no apparent authigenic enrichment. The samples with the highest $\mathrm{Si} / \mathrm{Al}$ have the highest $\mathrm{EF}$ in $\mathrm{Zr}$, and to a lesser degree, $\mathrm{Cr}$ and $\mathrm{Th}$, which is attributed to the presence of heavy minerals in association with the silt-size fraction of these four samples. In addition, the samples with the highest organic contents yield the highest enrichment factors in $U$ and Mo (samplesN1, N2, NN2 $\& N N 3)$; nevertheless, even in this case, the enrichment factors keep at low values. Compared to the other trace elements, the metalloids $\mathrm{As}$ and $\mathrm{Sb}$ show relatively high enrichment factors; however in contrast to what is observed for the Bancs Jumeaux, no correlation is observed with iron or phosphorus, and, furthermore, Sb-EF is correlated to Th-EF $\left(\mathrm{R}^{2}=0.71\right)$, which is not true for As. Arsenic is correlated to no other element and shows relatively constant proportions (mean concentrations $8.3 \mathrm{ppm}$ with standard deviation 1.7).

Iron is slightly more abundant in the Bancs Jumeaux than in the Argiles de Chatillon (Fig. 2; Table 3). In the latter formation, the Fe/Al is most of the time close to the average upper crust value (0.44; McLennan, 2001) or slightly above it (mean $\mathrm{Fe} / \mathrm{Al}=0.53 ; \mathrm{n}=63$ ), whereas $\mathrm{Fe} / \mathrm{Al}$ is consistently above this value in the Bancs Jumeaux Fm. (mean Fe/Al $=0.85$; $\mathrm{n}=17)$. In the Bancs Jumeaux Fm., Fe vs. Al relationship shows a determination coefficient $\mathrm{R}^{2}=0.62$. For the Argiles de Châtillon Fm., $\mathrm{R}^{2}=0.68$ for the sample set \#1 and 0.72 for the sample set \#2. In a $\mathrm{Fe}_{\text {total }}$ vs. Stotal crossplot (Lückge et al., 1996), the samples of the Bancs Jumeaux Fm. show a positive correlation, plotting above the theoretical pyrite line (Fig. 3). No such correlation is observed for the Argiles de Châtillon samples.

We calculated $\mathrm{F}_{\mathrm{exs}}$, namely, the part of the Fe content that is postulated to be in excess relative to the clastic fraction-associated part of the iron inventory (see Section 3). If we calculate the proportion of $\mathrm{F}_{\mathrm{exs}}$ relative to the total $\mathrm{Fe}$ content of the sample, we observe that, on average, $\mathrm{F}_{\text {exs }}$ represents $38 \%$ of total Fe inventory in the Bancs Jumeaux samples, and $16 \%$ only in the Argiles de Châtillon samples (Fig. 2). In the case of the Bancs Jumeaux Fm., Fexs shows correlations with phosphorus concentration and the following trace metals: Mo, As and 
$\mathrm{Sb}$ when the latter three elements are considered either as concentrations or enrichment factors. Noteworthily, the correlation between $\mathrm{P}$ from one side and $\mathrm{As}$ or $\mathrm{Sb}$ from the other side is even better than the correlation $\mathrm{F}_{\text {exs }}$ vs. As or Sb (Table 7; Fig. 4). However, the $\mathrm{F}_{\text {exs }}$ vs. Mo correlation is better than the P vs. Mo correlation. Lastly, Mo and As enrichment factors are correlated. No such correlations are observed with the Argiles de Châtillon samples (Table 7); what is described above is specific to the samples of the Bancs Jumeaux Fm.

EDS analyses and elemental mapping using SEM show that the phosphatic shells are made of oxygen, phosphorus, calcium, fluorine, sulfur and sodium. The composition of the various samples analyzed shows the following concentration ranges: oxygen 34.3-43.9 wt.\%; fluorine 10.6-12.5 wt.\%; phosphorus 8.5-11.8 wt.\%; calcium 29.5-35.2 wt.\%, sodium 0.50 .6 wt.\% and sulfur 1.1-5.6 wt.\%. This chemical composition suggests that the P-rich shells are made of francolite. SEM elemental mapping shows that the sediments contain abundant, scattered, tiny $\mathrm{P}$ concentrations.

The studied samples of the two formations yielded large pyrite grains (polyframboids), frequently measuring several tens of micrometers (Fig. 56 and see also details and

pictures in Tribovillard et al., 2008a). The $\delta^{34} \mathrm{~S}$ values of pyrite poly-framboids are ranging between -42.0 and $-26.9 \%$ CDT for the Bancs Jumeaux Fm., and between -9.9 and $0.2 \%$ CDT for the Argiles de Châtillon Fm. (Fig. 5).

\section{Interpretation}

\subsection{Bottom water redox conditions}

Concerning the Bancs Jumeaux Fm., it is already known that these sediments accumulated under dominant oxic-possibly suboxic conditions, and that they must have experienced the particulate shuttle process. The peculiar point regarding the trace metal content is an enrichment in Mo but not in any other element (Tribovillard et al., 2008a, 2012a, 2012b).

In the case of the Argiles de Châtillon Fm., we observe no significant enrichments in redox-sensitive and/or sulfide-forming elements in the mudstone samples, while the four samples of laminated black shales indicate some enrichment in both $U$ and Mo. It is inferred that sediment accumulation took place dominantly under normal, oxic conditions in the water column (mudstones), except for the episodes of laminated black shale deposition that 
corresponded to dysaerobic conditions. This interpretation finds some confirmation with the presence of benthic foraminifers (dominating Lenticulina, also present in the laminated black shales; unpublished Master thesis of T. Adesina).

Nickel and copper can be used as paleoproductivity proxies (see discussion in Calvert and Pedersen, 1993; Sageman and Lyons, 2003; Brumsack, 2006; Tribovillard et al., 2008b; Böning et al., 2009). No strong productivity was recorded by the Argiles de Châtillon rocks, as indicated by the absence of enrichments in $\mathrm{Ni}$ and $\mathrm{Cu}$. These conclusions are consistent with those of a modeling by Tribovillard et al. (2001) pointing to a productivity level comparable to what is currently observed on marine platforms.

Regarding the redox proxies of the Argiles de Châtillon samples, the clear correlation between $\mathrm{V}$ and $\mathrm{Al}$ shows that bottom conditions did not lead to authigenic enrichments in $\mathrm{V}$. In addition, except for the four OM-richest samples, no significant enrichment is observed in Mo and U (Table 4 and Fig. 6), which suggest that bottom-water conditions were not oxygenrestricted or reducing during deposition of the mudstone facies. For the four OM-richest samples (laminated black shale facies), U-enrichment is weak, which suggests dysaerobic conditions developing at the sediment water interface; Mo-EFs are only modestly higher. In the absence of marked $\mathrm{V}$ enrichment, this modest Mo enrichment is ascribed to the easy capture of Mo by organic S-rich OM (Tribovillard et al., 2004b).

The correlation between $\mathrm{Sb}$ and $\mathrm{Th}$ suggests that $\mathrm{Sb}$ has been supplied with some clastic, land derived, sediment fraction; the moderate and constant As enrichment cannot be accounted for by any correlation with other major or trace elements and remain unexplained here. A possible explanation is that a specific, As-rich lithology would have been eroded in the hinterland supplying the Boulonnais area with clastic fractions.

To sum up, the distribution of the redox-sensitive elements indicates that the Argiles de Châtillon Fm. accumulated under largely normal marine, oxic conditions, with possible short shifts to dysaerobic conditions during episodes of high OM-accumulation (laminated black shales). These conclusions match with what has been previously concluded for the Bancs Jumeaux Fm., with the only difference that the latter formation benefited from the particulate shuttle effect.

\subsection{Reactive iron availability}


A striking feature of our results is the relationship linking Fe, $\mathrm{P}$ and the trace metals $\mathrm{Mo}, \mathrm{As}$ and $\mathrm{Sb}$ in the case of the Bancs Jumeaux Fm. The first point is about the relative abundance of iron in excess to the fraction linked to the detrital content of the samples $\left(\mathrm{F}_{\mathrm{exs}}\right)$, which can be observed for the Bancs Jumeaux Fm. $\mathrm{F}_{\mathrm{exs}}$ is considered to be a good estimate of the reactive-iron supply to the sediments. $F_{\text {exs }}$ can be supplied mainly through the rain of settling Fe oxy-hydroxides when the water column is under oxidizing conditions or through the rain of iron sulfides $\left(\mathrm{FeS}\right.$ or $\left.\mathrm{FeS}_{2}\right)$ when the lower part of the water column is sulfidic (in case of euxinic conditions). The Bancs Jumeaux Fm. shows trace-metal abundances indicating that their sediments did not accumulate under reducing, oxygen-restricted conditions. Consequently, the syngenetic formation of iron sulfides within the water column may be ruled out for the Bancs Jumeaux. Thus the $\mathrm{F}_{\text {exs }}$ supply is inferred to result from Feoxy-hydroxides settling in a 'normal marine' seawater mass. The Bancs Jumeaux Fm. is already known to have experienced the particulate shuttle effect as evidenced from the differences between Mo- and U-enrichment factors (Tribovillard et al., 2012b). Our results about $U$ and Mo show that the Argiles de Châtillon did not experience such shuttle process. It comes out that, with no particulate shuttle, the iron content of the Argiles de Châtillon is expectedly closer to the average crustal content than in the case of the Bancs Jumeaux Fm. that has an additional source of iron through particulate shuttle. This is corroborated by the fact that, contrary to the Argiles de Châtillon that shows no correlation between Fe and S, the Bancs Jumeaux samples plot above the theoretical pyrite line, which indicates that sulfur must have been completely fixed into pyrite, leaving an excess fraction of reactive unsulfidized iron (Lückge et al., 1996).

\subsection{Reactive iron as a cause of enrichment in $P, M o$, As and $S b$}

In the case of the Bancs Jumeaux Fm., $F_{\text {exs }}$ is correlated to P, As, and, to a lesser degree, Sb, while such correlations are not apparent in the Argiles de Châtillon Fm.

\subsubsection{Phosphorus}

Phosphorus can be supplied to the sediments through OM inputs; subsequent OM decomposition would release $\mathrm{P}$ to pore waters, making it available for diagenetic relocation or return to the water column. Phosphorus can lastly be provided by phosphate-rich particles such as fish bones and scales, and in association (adsorption + co-precipitation) with the settling flux of Fe oxy-hydroxides (Ingall and Van Cappellen, 1990; Ingall et al., 1993; van 
Cappellen and Ingall, 1994; Föllmi, 1996; Slomp et al., 1996; Anderson and Raiswell, 2004; März et al., 2008, 2014; Breier et al., 2012). After deposition, the transfer of P from the labile P-carrying phases (OM, Fe oxy-hydroxides, hydroxyapatite) into authigenic apatite is the dominant and ultimate P sink with increasing sediment age and burial depth (Delaney, 1998; Anderson et al., 2001; Slomp and Van Cappellen, 2007; März et al., 2008; Piper and Perkins, 2014).

In the present work, the facts that 1) $\mathrm{F}_{\text {exs }}$ and $\mathrm{P}$ are correlated in the Bancs Jumeaux sample set and not in that of the Argiles de Châtillon, and 2) the Argiles de Châtillon Fm. though richer in OM than the Bancs Jumeaux Fm., is poorer in P, strongly suggest that the main supplier of $\mathrm{P}$ to the sediment of the Bancs Jumeaux was the iron shuttle, which does not exclude a possible additional supply by biogenic fractions. For the Argiles de Châtillon Fm. with no shuttle effect, the iron oxyhydroxides could not be an important carrier of $\mathrm{P}$ (no $\mathrm{F}_{\mathrm{exs}}$ - P correlation are observed) and biogenic phases must have been the main suppliers (TOC and $\mathrm{P}$ are correlated, Table 7). For these two formations, the absence of strongly reducing conditions during deposition (except for the laminated black shales) allows us ruling out any significant, early diagenetic, loss of P (e.g., Jarvis et al., 1994; Föllmi, 1996; Filippelli, 2001; Algeo and Ingall, 2007; Reed et al., 2011). In addition, both formations have been interpreted to have experienced relatively low productivity (close to present open shelves, see above) and Schenau et al. (2005) discussed how, during periods of reduced productivity, a limited supply of $\mathrm{OM}$ would increase oxygen penetration depth into sediments, and thus the sorption capacity of the iron oxides for phosphate. Furthermore, bioturbation may play a role: downward mixing of solid-phase reactive $\mathrm{P}$ may be essential to prevent direct loss of phosphate to the bottom waters (Schenau et al., 2005; Meyers, 2007).

In the Bancs Jumeaux Fm., $\mathrm{P}$ appears both as francolite replacing carbonate in bivalve shells, as well as in tiny P-rich particles densely scattered within the sediment matrix. It is not easy deciphering whether phosphate precipitation took place during the earliest stages of diagenesis or during further steps. Francolite precipitation is conditioned by alkalinity, $\mathrm{pH}$, Eh and bacterial activity (Reimers et al., 1996; Benitez-Nelson, 2000). Francolite can precipitate either rapidly (most probably replacing a short-lived and poorly crystallized precursor (Föllmi, 1996)) or slowly (usually replacing calcite but possibly directly also; Föllmi, 1996; Jarvis et al., 1994; Piper and Perkins, 2004, 2014; Trappe, 1998). The P concentration must be high enough to support francolite super saturation. This enrichment may result from a high organic matter supply in highly productive marine environments such as upwelling areas 
(Arning et al., 2009a, 2009b), but high productivity is not always a prerequisite. In lowproductivity portions of the seas, it is often considered that $\mathrm{P}$ enrichment can be effectuated by redox cycling of iron, with $\mathrm{P}$ sorption onto iron-oxy-hydroxide coatings and $\mathrm{Fe}-\mathrm{P}$ coprecipitation (e.g., Jarvis et al., 1994; Piper and Perkins, 2004; Dellwig et al., 2010; n.b., manganese also can be involved in P enrichment; Wang and van Cappellen, 1996).

The degree to which remineralized organic $\mathrm{P}$ is retained as a reactive fraction in sediments depends on the redox conditions of the depositional system (Slomp et al., 1996). In environments with at least intermittently oxic bottom waters, redox cycling of Fe within the sediment limits the diffusive flux of remineralized $\mathrm{P}$ to the overlying water column: Fe oxyhydroxides that scavenge phosphate from sediment pore waters are precipitated above the oxic/anoxic interface and dissolved below it, leading to retention of $\mathrm{P}$ for a period sufficient to permit slow growth of authigenic phosphate phases. In permanently anoxic environments with sulfidic bottom waters, Fe-oxy-hydroxides do not precipitate within the sediment, reducing the potential for adsorption and complexation of remineralized organic P. Lastly, sulfatereducing conditions are generally considered to prevent francolite formation because the correlative rise in alkalinity increases francolite solubility and prevents supersaturation to be reached and thus precipitation to take place (Cha et al., 2005; Soudry, 2000; Trappe, 1998; and references therein). Consequently, francolite is generally presented as precipitating under suboxic conditions and not anoxic-sulfidic conditions (Froelich et al., 1988; Jarvis et al., 1994; Föllmi, 1996; Piper and Perkins, 2014). However, some recent works challenged this view (Goldhammer et al., 2010).

\subsubsection{Mo, As and Sb}

In the Bancs Jumeaux sample set, correlations are observed between $\mathrm{F}_{\mathrm{exs}}$ on one hand, and $\mathrm{Mo}$, As and $\mathrm{Sb}$ on the other hand. The relationship between $\mathrm{F}_{\mathrm{exs}}$ and Mo can clearly be attributed to the role of iron (and manganese) oxy-hydroxides through particulate shuttle processes, as detailed in Algeo and Tribovillard (2009), Helz et al. (2011), Scholz et al. (2011, 2013), and Scott and Lyons (2012). The relationship between $F_{\text {exs }}$ and As can be attributed to the same phenomenon, because the role of iron oxy-hydroxides in the transfer of As from the water column to the sediments has been well explored (Sullivan and Aller, 1996; Minami and Kato, 1997; Cutter et al., 2001; Chaillou et al., 2003; O'Day, 2006; Vaughan, 2006; Breier et al., 2012; Berner et al., 2013; Neumann et al., 2013). The same is true for $\mathrm{Sb}$, because $\mathrm{Sb}$ and As are considered to have similar geochemical properties in marine and also river systems 
(e.g., Cutter et al., 2001; Asaoka et al., 2012). Here, if we except the most phosphate-rich sample, a mean 4.2 enrichment factor is observed for $\mathrm{Sb}$ in the Bancs Jumeaux, which is a relatively high value for sedimentary rocks. No such relationships can be observed for the Argiles de Châtillon samples, whatever their organic content, in agreement with the absence of iron shuttle.

In total, we can consider that Mo, As and Sb have been brought to the sediments of the Bancs Jumeaux Fm. together with iron oxy-hydroxides. During diagenesis, the trace metals must have been incorporated into pyrite, taking into account the high degree of trace-metal pyritization known for Mo, As and Sb (Huerta-Diaz and Morse, 1992; Bostick and Fendorf, 2003; Couture et al., 2010; Berner et al., 2013).

\section{4. $\delta^{34} \mathrm{~S}$ of pyrite}

The isotopic signatures of the large pyrite (poly-) framboids show contrasting value ranges between the two formations, with significantly lower $\delta^{34} \mathrm{~S}$ for the Bancs Jumeaux Fm. (Fig. 5). By and large, lower $\delta^{34} \mathrm{~S}$ values are often associated with early diagenetic pyrite relative to later diagenetic phases (e.g., Canfield et al., 1992) because of progressive isotopic evolution of the sulfate reservoir as isotopically light sulfur is preferentially reduced during bacterial sulfate reduction. Under these later burial stages, far removed from the overlying seawater reservoir, there would be less light $\mathrm{S}$ availability in the pore waters and thus less incorporation into later pyrite (see Chappaz et al., 2014). In the present case, we compare two populations of framboids, i.e., a type of pyrite morphology that is considered to form during early diagenesis. Regarding the Bancs Jumeaux Fm., where pyrite framboids yield more isotopic fractionation, we may infer that sulfate availability was not a limiting factor. It means that the redox front was at close distance below the sediment-water interface, which allowed sulfate diffusion from the seawater reservoir down to the bacterial sulfate-reduction zone. In parallel, such a setting is consistent with the Mo enrichment as discussed in Tribovillard et al. (2008a). In the case of the Argiles de Châtillon Fm., within the mudstone facies, the redox front would have been lying deeper below the sediment-water interface, hampering sulfate diffusion down to the sulfate-reduction zone and leading to less fractionation. This interpretation of the isotope data is consistent with trace metal distribution for the mudstone facies. 
Alternatively, contrasting conditions of initial sediment porosity could be invoked to account for contrasting isotope fractionation, but we have no indication that such initial differences might have existed. Lastly, it might also be suggested that these framboids formed from an iron pool that was released shortly after deposition, e.g., through the alteration of Ferich minerals (smectites, for instance; Canfield et al., 1992).

\section{Discussion}

\subsection{Co-enrichment in Fe, P, Mo, As and Sb as a proxy for the particulate shuttle process}

The Bancs Jumeaux sediments experienced deposition under conditions promoting particulate shuttling of trace elements by Fe- (and possibly Mn-) oxy-hydroxides. The shuttle process is already known to favor Mo enrichment (Dale et al., 2012; Berelson et al., 2013), but from the present study, we conclude that the shuttle process may also cause some enrichment in $\mathrm{P}$ and As, as well as $\mathrm{Sb}$, though to a lesser degree in the latter case. Such a coenrichment in $\mathrm{Fe}$, Mo, As and $\mathrm{Sb}$ was already observed in some particular settings: cold hydrocarbon seepages in Southeastern France (Jurassic Terres Noires Fm.; Tribovillard et al., 2013) and in the pockmark field of the Congo Fan and Gulf of Mexico (Hu et al., 2014; see also Bayon et al., 2011). Reciprocally, we suggest that a correlation between iron ( $\left.F_{\text {exs }}\right)$ and Mo, P, As (and Sb) could indicate that an iron shuttle process was operated by the time of sediment settling. However, caution must be taken, because syngenetic pyrite (i.e., formed directly with the water column of euxinic environments) may also incorporate $\mathrm{Mo}$, As and $\mathrm{Sb}$ present in seawater (Berner et al., 2013). However, in the latter case, the development of euxinic conditions induces pronounced enrichments in Mo and $U$, in particular. Consequently, to conclude that $\mathrm{Mo}, \mathrm{P}, \mathrm{As}$ and $\mathrm{Sb}$ are enriched via the iron shuttle process, $\mathrm{U}$ concentrations cannot be markedly enriched.

\subsection{Lack of reactive iron favored early natural sulfurization of OM}

A second important finding of this work is that one can observe a marked enrichment in organic S-rich OM (or sulfurized OM) in the Argiles de Châtillon that could occasionally accumulate several weight percents of vulcanized OM. This unusual S-rich OM accumulation took place under conditions of modest productivity. Such an observation is quite unusual inasmuch as accumulation of abundant, sulfurized OM has been reported hitherto for (paleo-) environments characterized by high productivity and/or low terrigenous supply (carrier phase 
for reactive iron). See review in Vandenbroucke and Largeau (2007). In brief, OM sulfurization takes place when sulfide ions $\left(\mathrm{HS}-/ \mathrm{H}_{2} \mathrm{~S}\right)$ can react with functionalized organicmolecules, which implies that all the sulfide ions are not monopolized by Fe(II). In other words, there must be an iron deficiency, either relative or absolute. If little or no reactive iron is supplied to the depositional environment, the iron deficiency will be absolute. If reactive iron is supplied, but if a marked organic flux is also present (high productivity), the large amount of sulfide ions generated through sulfate reduction linked to bacteriallymediated OM decay will exhaust the reactive iron pool, and sulfide will be available for sulfurization (Zaback et al., 1993; Tribovillard et al., 1994). Here, in the case of the Argiles de Châtillon, sulfate-reducing reactions, induced by bacterially-mediated OM remineralization, operated with sediments rich in land-derived, clastic fractions, but limited in reactive iron (despite abundant silt and clay fractions). Consequently, OM could react with " unemployed" or excess sulfide ions and incorporate S. This so-called natural vulcanization protected OM against further degradation and permitted its accumulation in noticeable amounts. The conspicuous point is that the reactive-iron limitation triggered $\mathrm{OM}$ sulfurization with relatively little $\mathrm{OM}$ present. The remineralization of a large pool of MO was not required to produce enough sulfide to immobilize reactive iron. Consequently, although the OM flux must have been moderate (moderate surface productivity), OM was protected through sulfur incorporation and stored in relatively large amounts.

The role of iron as a factor favoring OM remineralization was discussed by Meyers et al. (2005) and Meyers (2007). In the arguments of the authors, a relatively abundant flux of reactive iron will allow buffering of dissolved sulfide via iron sulfidization (see also Canfield et al., 1992; Raiswell and Canfield, 1996). Dissolved sulfide is thus made "harmless", allowing for the presence of in fauna. This, in turn, will increase bioturbation and bioirrigation, required to maintain oxidants such as dissolved oxygen and nitrate in pore waters, and hence enhance OM remineralization. Furthermore, active bioturbation and bioirrigation can expand the zone of aerobic OM degradation, thus increasing the exposure time of OM to dissolved oxygen. Conversely, these factors fostering OM degradation will be much tempered in case of reactive-iron limitation (Meyers, 2007). Our work adds one positive effect of iron limitation: the sulfide ions, maintained at relatively high concentration in the dissolved state if iron-induced buffering cannot take place, will induce OM sulfurization, hence further promoting OM preservation and burial. 
Carbonate rocks are often poor in reactive iron and, in some occasions, they may be strongly enriched in sulfured AOM. This is the case for some Late Jurassic formations deposited in shallow platform environments: e.g., the Akkuyu Fm. of Turkey (Baudin et al., 1999) and the "Laminites bitumineuses" of Orbagnoux in the French Jura Mountains (Mongenot et al., 1997, 1999; Sarret et al., 2002). For these formations, OM sulfurization was ascribed to reactive-iron limitation. In addition, carbonate rocks are sometimes good petroleum source rocks and their kerogens are most of the time of the type II-S, which means that the OM is enriched in organic S(Jones, 1984; Oehler, 1984; Palacas et al., 1984; Claypool and Mancini, 1989; Taguchi and Mori, 1992). Thus, even carbonate rocks can also contain $\mathrm{OM}$ that has been preserved by sulfurization processes induced by iron limitation. However, most carbonate rocks, even when poor in reactive iron, are not rich in $\mathrm{S}$ containing $\mathrm{OM}$, implying that reactive-iron shortage alone cannot account for OM preservation in any situation. It is an important factor that plays its full role when other factors operate in conjunction: a level of productivity that must remain above a minimum threshold, and anoxic conditions occurring at relatively shallow depth below the sediment-water interface. This latter point is required for sulfate reducing reactions to be launched, thus producing sulfide that will sulfurize organic molecules (lipids and carbohydrates).

Moving from the general case to the particulars of this study, in the case of the Argiles de Châtillon and Bancs Jumeaux Fms., other local factors may have played a significant role. One factor favoring the preservation of $\mathrm{OM}$ was the shallow water conditions during deposition of both formations, which limited the exposure time to oxidizing conditions during OM settling. A second favoring factor is the sedimentation rate. Sedimentation rate was higher for the Argiles de Châtillon Fm. than for the Bancs Jumeaux Fm., which helped limit the exposure time of $\mathrm{OM}$ to dissolved oxygen-containing pore waters in the Argiles de Châtillon Fm.

\subsection{Reactive iron supply}

Now that the consequences of the presence or absence of a detectable reactive-iron supply to sediments have been discussed, the question arises why the Bancs Jumeaux experienced a higher iron supply compared to the Argiles de Châtillon showing a terrigenous supply with a "normal", average shale-type, concentration in iron. Usually, iron is supplied to the depositional environment on platforms in two ways: allochthonous supply by winds and 
rivers, and autochthonous redistribution from proximal settings to distal ones (review in Raiswell and Canfield, 2012).

\subsubsection{External inputs}

The two formations studied were deposited during a large second-ordersea- level rise (Tribovillard et al., 2005) and both correspond to periods of relatively distal conditions accompanied by occasionally reduced sedimentation rates (see Proust et al., 1995 or Wignall and Newton, 2001 for a detailed sequence stratigraphy description). The reactive-iron supply to the basin may have been conditioned by several factors: 1) the relative width of the platform being flooded during sea-level rise; 2) the flux of river-borne (Severmann et al., 2010) or airborne (e.g., Baddock et al., 2013; Buck et al., 2013) iron-coated particles; and 3) the flux of OM possibly associated with reactive iron (e.g., Krachler et al., 2012; Bressac and Huieu, 2013; Shigemitsu et al., 2013; Barber et al., 2014). Discussing these factors is rather conjectural in the case in point here, but it may be observed that the sediments of the Bancs Jumeaux are richer in smectite and poorer in kaolinite than those of the Argiles de Chattillon Fm. It is suggested that smectite could have been a Fe-carrying phase operating more efficiently in the case of the Bancs Jumeaux Fm. (see Canfield et al., 1992; 1996).

The scenario asking for the minimum hypotheses is basing upon contrasting sedimentation rates. As reminded above, $\mathrm{F}_{\mathrm{exs}}$ can be supplied mainly through the rain of settling Fe oxy-hydroxides (particulate) when the water column is under oxidizing conditions. The sedimentation rate was probably lower during the deposition of the Bancs Jumeaux compared to the Argiles de Châtillon. A reduced sedimentation rate usually favors iron accumulation because the settling Fe-oxyhydroxidesis no longer "diluted" by the terrigenous supply nor by autochthonous biogenic particles (this process may cause the iron or manganese encrustation of hardgrounds in the case of extremely reduced sedimentation rates). In this view, the Bancs Jumeaux could have been enriched in iron simply as a result of a reduced sedimentation rate. In contrast, the Argiles de Châtillon experienced a relatively higher sedimentation rate due to a higher clastic supply and they accumulated iron in the same proportions as those of the so-called average shale.

\subsubsection{Internal redistribution}


Iron may have been redistributed with the marine environment itself. The current model (Poulton and Raiswell, 2002; Anderson and Raiswell, 2004; Lyons and Severmann, 2006 and further developments in Owens et al., 2012; Rickard, 2012; Scholz et al., 2014) suggests that detrital iron deposited on the shelf undergoes suboxic diagenesis, which generates aqueous Fe (II). This iron diffuses from the sediment to the sediment-water interface where it is oxidized and precipitated as Fe (III) oxy-hydroxides. However a fraction appears to be transported to the deeper, euxinic parts of the basin where it is sequestered as iron sulfide. It is possible that, like the finer sediment fraction, these Fe (III) oxy-hydroxide particles accumulated slowly and are thus concentrated in the deeper parts of the basin with the siliciclastic clay fraction (Rickard, 2012). This scheme (normally applying to deeper environments) is all the more interesting for the present study in that it agrees with previous observations by Wignall and Newton (2001). These authors described a proximal-to-distal trend from the north of the Boulonnais (close to the Gris-Nez Cape) to the south (close to Boulogne city). Contrary to expectation, their work clearly indicates the development of oxygen-poor deposition in relatively shallow-water setting ( $\mathrm{N}$ of the Boulonnais), passing down-dip into better oxygenated facies in the vicinity of the sections studied here. They conclude that "the salient point here is that black shale deposition on the Boulonnais Basin margin occurred above 'normal' storm wave base". Wignall and Newton (2001) suggested that the transgressive, near shore black shales recorded deposition beneath a small volume of sulfidic bottom water, trapped beneath an unusually shallow pycnocline developed during the initial phases of parasequence deposition. A point of cornerstone importance for the present paper is the development of euxinic conditions of deposition (long-lasting or intermittent) in the north of the Boulonnais "which would have decreased the importance of lateral Fe advection"(Wignall and Newton, 2001). This scheme explains why the deeper parts of the Boulonnais (i.e., the sections between Wimereux and Boulogne studied here) collected only limited amounts of reactive iron, during the deposition of the Argiles de Châtillon Fm.

It may be noted that the model of (very) shallow environments being submitted to anoxic-to-euxinic conditions has been illustrated recently: e.g., Bond et al. (2013) and Carmichael et al. (2014) for the Late Devonian events of Canada and Central Asia, respectively; Stein et al. (2012) for the Barremian-Aptian transition on the N-Tethyan platform, and März et al. (2011b) for the Eocene Arctic Ocean. Such a model is somewhat counter-intuitive in that one might think that supra-thermoclinal depositional conditions, as may be met in platform settings, must be oxygen-replenished through easy exchanges with 
atmosphere. To account for shallow, oxygen-restricted, depositional conditions, the authors invoke climate warming, that may contribute to the development of anoxic-dysoxic waters in shallow environments due to the decreased $\mathrm{O} 2$-solubility in warmer water, as well as the greater metabolic demand for oxygen as temperature increases (Bond et al., 2013).

To conclude with this point, it is observed that seasonal hypoxia/ anoxia may develop year after year in some present-time embayments that have dimensions comparable to those of what was the Boulonnais during the late Jurassic times (e.g., Li et al., 2014). In the same way, we may envision that such seasonal hypoxia/anoxia could develop in the proximal environment of the Jurassic Boulonnais, limiting lateral advection of iron, as mentioned by Wignall and Newton (2001).

\section{Summary}

The scenario presented here is summarized in Table 8 . The main conclusions of this study are of interest on two fronts:

1 Paleoenvironmental reconstructions. The particulate iron shuttle may cause enrichments of Mo, P, As and $\mathrm{Sb}$ in marine sediments. Reciprocally, co-enrichments in Mo, $\mathrm{P}, \mathrm{As}$ and $\mathrm{Sb}$ may be used to identify a paleo-shuttle effect if $\mathrm{U}$ enrichments are lacking.

2 OM preservation. A limitation in reactive iron during deposition may lead to vulcanization-induced preservation of $\mathrm{OM}$, even in marine settings with only modest productivity.

In summary, we suggest that iron limitation is a key factor conditioning both the organic and inorganic geochemistry of margin sediments.

\section{Acknowledgments}

We thank Romain Abraham, Laurence Debeauvais, Marion Delattre, Philippe Recourt, and Sandra Ventalon for their technical assistance,

and Monique Gentric for her administrative management. Thanks to Adewale Adesina for picking forams in some of our samples. Thanks to Magali Ader for her fruitful discussions. This paper was considerably improved thanks to suggestions by Christian März and two anonymous referees, as well as Michael E. Böttcher, co-editor of Chemical Geology. 
This work was partly funded by INSU, CNRS program SYSTER.

\section{References}

Algeo, T.J., Ingall, E., 2007. Sedimentary Corg:P ratios, paleocean ventilation, and Phanerozoic atmospheric pO2. Palaeogeogr. Palaeoclimatol. Palaeoecol. 256, 130-155.

Algeo, T.J., Lyons, T.W., 2006. Mo-total organic carbon covariation in modern anoxic marine environments: implication for analysis of paleoredox and paleohydrographic conditions. Paleoceanography 21, PA1016. http://dx.doi.org/10.1029/2004PA001112.

Algeo, T.J., Tribovillard, N., 2009. Environmental analysis of paleoceanographic systems based on molybdenum-uranium covariation. Chem. Geol. 268, 211-225.

Al-Ramadan, K., Morad, S., Proust, J.-N., Al-Aasm, I., 2005. Distribution of diagenetic altérations in siliciclastic shoreface deposits within a sequence stratigraphic Framework: évidence from the upper Jurassic Boulonnais, NWFrance. J. Sediment. Res. 75, 943-959.

Anderson, T.F., Raiswell, R., 2004. Sources and mechanisms for the enrichment of highly reactive iron in euxinic Black Sea sediments. Am. J. Sci. 304, 203-233.

Anderson, L.D., Delaney, M.L., Faul, K.L., 2001. Carbon to phosphorus ratios in sediments: implications for nutrient cycling. Glob. Biogeochem. Cycles 15, 65-79.

Arning, E.T., Birgel, D., Brunner, B., Peckmann, J., 2009a. Bacterial formation of phosphatic laminites off Peru. Geobiology 7, 295-307.

Arning, E.T., Lückge, A., Breuer, C., Gussone, N., Birgel, D., Peckmann, J., 2009b. Genesis of phosphorite crusts off Peru. Mar. Geol. 262, 68-81.

Asaoka, S., Takahashi, Y., Araki, Y., Tanimizu, M., 2012. Comparison of antimony and arsenic behavior in an Ichinokawa river water-sediment system. Chem. Geol. 334, 1-8.

Baddock, M., Boskovic, L., Strong, C., McTainsh, G., Bullard, J., Agranovski, I., Cropp, R., 2013. Iron-rich nanoparticles formed by aeolian abrasion of desert dune sand. Geochem. Geophys. Geosyst. 14, 3720-3729.

Barber, A., Lalonde, K., Mucci, A., Gélinas, Y., 2014. The role of iron in the diagenesis of organic carbon and nitrogen in sediments: a long-term incubation experiment. Mar. Chem. $162,1-9$. 
Baudin, F., Tribovillard, N., Laggoun-Defarge, F., Lichtfouse, E., Monod, O., Gardin, S., 1999. Depositional environment of a Kimmeridgian carbonate "black band" (Akkuyu Fm., SWTurkey). Sedimentology 46, 589-602.

Bayon, G., Birot, D., Ruffine, L., Caprais, J.-C., Ponzevera, E., Bollinger, C., Donval, J.-P., Charlou, J.-L., Voisset, M., Grimaud, S., 2011. Evidence for intense REE scavenging at cold seeps from the Niger Delta margin. Earth Planet. Sci. Lett. 312, 443-452.

Benitez-Nelson, C.R., 2000. The biogeochemical cycling of phosphorus in marine systems. Earth Sci. Rev. 51, 109-135.

Berelson, W.M., McManus, J., Severmann, S., Reimers, C.E., 2013. Benthic flux of oxygen and nutrients across Oregon/California shelf sediments. Cont. Shelf Res. 55, 66-75.

Berner, R.A., 1970. Sedimentary pyrite formation. Am. J. Sci. 268, 1-23.

Berner, R.A., 1984. Sedimentary pyrite formation: an update. Geochim. Cosmochim. Acta 48, $605-615$.

Berner, Z.A., Puchelt, H., Nöltner, T., Kramar, U., 2013. Pyrite geochemistry in the Toarcian Posidonia Shale of south-west Germany: evidence for contrasting trace-element patterns of diagenetic and syngenetic pyrites. Sedimentology 60, 548-573.

Bialkowski, A., Tribovillard, N., Vergès, E., Deconinck, J.-F., 2000. Etude haute résolution de la distribution et de la granulométrie des constituants organiques sédimentaires. Corrélations avec les variations du niveau marin. Kimméridgien/Tithonien du Boulonnais (Nord de la France). CR Acad. Sci. Paris II 331, 451-458.

Bond, D.P., Zatoń, M., Wignall, P.B., Marynowski, L., 2013. Evidence for shallow-water 'Upper Kellwasser'anoxia in the Frasnian-Famennian reefs of Alberta, Canada. Lethaia 46, $355-368$.

Böning, P., Brumsack, H.-J., Schnetger, B., Grunwald, M., 2009. Trace element signatures of Chilean upwelling sediments at $\sim 36^{\circ}$ S. Mar. Geol. $259,112-121$.

Bostick, B.C., Fendorf, S., 2003. Arsenite sorption on troilite (FeS) and pyrite (FeS2). Geochim. Cosmochim. Acta 67, 909-921.

Boussafir, M., Lallier-Vergès, E., Bertrand, Ph., Badaut-Trauth, D., 1994. Structure ultrafine de la matière organique dans des roches mères du Kimméridgien du Yorkshire (UK). Bull. Soc. Géol. Fr. 165, 353-361. 
Boussafir, M., Gelin, F., Lallier-Vergès, E., Derenne, S., Bertrand, Ph., Largeau, C., 1995a. Electron microscopy and pyrolysis of kerogens from the Kimmeridge Clay Fm., UK: source organisms, preservation processes and origin of microcycles. Geochim. Cosmochim. Acta 59, $3731-3747$.

Boussafir, M., Lallier-Vergès, E., Bertrand, Ph., Badaut-Trauth, D., 1995b. SEM and STEM studies on isolated organic matter and rock microfacies from a short-term organic cycle of the Kimmeridge Clay Formation (Yorkshire, UK). In: Lallier-Vergès, E., Tribovillard, N.-P., Bertrand, Ph. (Eds.), Organic Matter Accumulation. Lecture Notes in Earth Sciences 57. Springer, pp. 15-30.

Bout-Roumazeilles, V., Cortijo, E., Labeyrie, L., Debrabant, P., 1999. Clay-mineral evidence of nepheloid layer contribution to the Heinrich layers in the Northwest Atlantic. Palaeogeogr. Palaeoclimatol. Palaeoecol. 146, 211-228.

Braaksma, H., Proust, J.-N., Kenter, J.A.M., Drijkoningen, G.G., Filippidou, N., 2006. Sedimentological, petrophysical, and seismic characterization of an upper Jurassic shorefacedominated shelf margin (the Boulonnais, Northern France). J. Sediment. Res. 76, 175-199.

Breier, J.A., Toner, B.M., Fakra, S., Manganini, S.J., White, S.N., Thurnherr, A.M., German, C.R., 2012. Sulfur, sulfides, oxides, and organic matter aggregated in the deep-sea hydrothermal plumes 551 of $9^{\circ} 50^{\prime}$ N East Pacific Rise. Geochim. Cosmochim. Acta 88, 216236.

Bressac, M., Huieu, C., 2013. Post-depositional processes:what really happens to new atmospheric iron in the ocean's surface? Glob. Biogeochem. Cycles 27, 1-12. http:// dx.doi.org/10.1002/gbc.20076.

Brumsack, H.-J., 2006. The trace metal content of recent organic carbon-rich sediments: implications for Cretaceous black shale formation. Palaeogeogr. Palaeoclimatol. Palaeoecol. $232,344-361$.

Buck, C.S., Landing,W.M., Resing, J.A., 2013. Pacific Ocean aerosols: deposition and solubility of iron, aluminum, and other trace elements. Mar. Chem. 157, 117-130.

Calvert, S.E., Pedersen, T.F., 1993. Geochemistry of recent oxic and anoxic sediments: implications for the geological record. Mar. Geol. 113, 67-88.

Canfield, D.E., Raiswell, R., Bottrell, S., 1992. The reactivity of sedimentary iron minerals toward sulfide. Am. J. Sci. 292, 659-683. 
Canfield, D.E., Lyons, T.W., Raiswell, R., 1996. A model for iron deposition to euxinic Black Sea sediments. Am. J. Sci. 296, 818-834.

Carignan, J., Hild, P., Morel, J., Yeghicheyan, D., 2001. Routine analysis of trace elements in geochemical samples using flow injection and low-pressure on-line liquid chromatography coupled to ICP-MS: a study of geochemical references materials BR,DR-N, UB-N, AN-G and GH. Geostand. Newslett. 25, 187-198.

Carmichael, S.K., Waters, J.A., Suttner, T.J., Kido, E., DeReuil, A., 2014. A new model for the Kellwasser Anoxia Events (Late Devonian): shallow water anoxia in an open oceanic setting in the Central Asian Orogenic Belt. Palaeogeogr. Palaeoclimatol. Palaeoecol. 399, 394-403.

Cha, H.J., Lee, C.B., Kim, B.S., Choi, M.S., Ruttenberg, K.C., 2005. Early diagenetic redistribution and burial of phosphorus in the sediments of the southwestern East Sea (Japan Sea). Mar. Geol. 216, 127-143.

Chaillou, G., Schäfer, J., Anschutz, P., Lavaux, G., Blanc, G., 2003. The behaviour of Arsenic in the muddy sediments of the Bay of Biscay (France). Geochim. Cosmochim. Acta 67, 29933003.

Chappaz, A., Gobeil, C., Tessier, A., 2008. Geochemical and anthropogenic enrichments of Mo in sediments from perennially oxic and seasonally anoxic lakes in Eastern Canada. Geochim. Cosmochim. Acta 72, 170-184.

Chappaz, A., Lyons, T.W., Gregory, D.D., Reinhard, C.T., Gill, B.C., LiC, Large, R.R., 2014. Does pyrite act as an important host for molybdenum in modern and ancient euxinic sediments? Geochim. Cosmochim. Acta 126, 112-122.

Claypool, G.E., Mancini, E.A., 1989. Geochemical relationships of petroleum in Mesozoic reservoirs to carbonate source rocks of Jurassic Smackover Formation, southwestern Alabama. AAPG Bull. 73, 904-924.

Couture, R.-M., Gobeil, C., Tessier, A., 2010. Arsenic, iron and sulfur co-diagenesis of in lake sediments. Geochim. Cosmochim. Acta 74, 1238-1255.

Crusius, J., Calvert, S., Pedersen, T., Sage, D., 1996. Rhenium and molybdenum enrichments in sediments as indicators of oxic, suboxic and sulfidic conditions of deposition. Earth Planet. Sci. Lett. 145, 65-78. 
Cutter, G.A., Cutter, L.S., Featherstone, A.M., Lohrenz, S.E., 2001. Antimony and arsenic biogeochemistry in the western Atlantic Ocean. Deep-Sea Res. II 48, 2895-2915.

Dale, A.W., Meyers, S.R., Aguilera, D.R., Arndt, S., Wallmann, K., 2012. Controls on organic carbon and molybdenum accumulation in Cretaceous marine sediments from the Cenomanian-Turonian interval including Oceanic Anoxic Event 2. Chem. Geol. 324-325, $28-45$.

Deconinck, J.-F., Geyssant, J.R., Proust, J.-N., Vidier, J.P., 1996. Sédimentologie et biostratigraphie des dépôts kimméridgiens et tithoniens du Boulonnais. Ann. Soc. Géol. Nord $4,157-170$.

Delaney, M.L., 1998. Phosphorus accumulation in marine sediments and the oceanic phosphorus cycle. Glob. Biogeochem. Cycles 12, 563-572.

Dellwig, O., Leipe, T., März, C., Glockzin, M., Pollehne, F., Schnetger, B., Yakushev, E.V., Böttcher, M.E., Brumsack, H.-J., 2010. A new particulate Mn-Fe-P-shuttle at the redoxcline of anoxic basins. Geochim. Cosmochim. Acta 74, 7100-7115.

Derenne, S., Largeau, C., Casadevall, E., Berkaloff, C., Rousseau, B., 1991. Chemical evidence of kerogen formation in source rocks and oil shales via selective preservation of thin resistant outer walls of microalgae: origin of ultralaminae. Geochim. Cosmochim. Acta 55, $1041-1050$.

Espitalié, J., 1993. Rock Eval pyrolysis. In: Bordenave, M.L. (Ed.), Applied Petroleum Geochemistry. Technip, Paris, pp. 237-261.

Filippelli, G., 2001. Carbon and phosphorus cycling in anoxic sediments of the Saanich Inlet, British Columbia. Mar. Geol. 174, 307-321.

Föllmi, K.B., 1996. The phosphorus cycle, phosphogenesis and marine phosphate-rich deposits. Earth Sci. Rev. 40, 55-124.

Froelich, P.N., Arthur, M.A., Burnett, W.C., Deakin, M., Hensley, V., Jahnke, R., Kaul, L., Kim,, K.-H., Roe, K., Soutar, A., Vathakanon, C., 1988. Early diagenesis of organic matter in Peru continental margin sediments: phosphorite precipitation. Mar. Geol. 80, 309-343.

Fürsich, F., Oschmann, W., 1986. Stormshell beds of Nanogyra virgula in the upper Jurassic of France. N. Jb. Geol. Paläont. Abh. 172, 141-161. 
Gelin, F., Boussafir, M., Derenne, S., Largeau, Cl, Bertrand, Ph., 1995. Study of qualitative and quantitative variations in kerogen chemical structure along a microcycle: correlation with ultrastructural features. In: Lallier-Vergès, E., Tribovillard, N.-P., Bertrand, Ph. (Eds.), Organic Matter Accumulation. Lecture Notes in Earth Sciences 57. Springer, pp. 32-47.

Gelin, F., Volkmann, J.K., Largeau, C., Derenne, S., Sinninghe Damsté, J.S., de Leeuw, J.W., 1999. Distribution of aliphatic, non-hydrolyzable biopolymers in marine microalgae. Org. Geochem. 30, 147-159.

Geyssant, J.R., Vidier, J.-P., Herbin, J.-P., Proust, J.N., Deconinck, J.-F., 1993. Biostratigraphie et paléoenvironnement des couches de passage Kimméridgien/Tithonien du Boulonnais (Pas de Calais): nouvelles données paléontologiques (ammonites), organisation séquentielle et contenu en matière organique. Géol. Fr. 4, 11-24.

Goldberg, T., Archer, C., Vance, D., Poulton, S.W., 2009. Mo isotope fractionation during adsorption to Fe (oxyhydr)oxides. Geochim. Cosmochim. Acta 73, 6502-6516.

Goldhammer, T., Brüchert, V., Ferdelman, T.G., Zabel, M., 2010. Microbial sequestration of phosphorus in anoxic upwelling sédiments. Nat. Geosci. 3, 557-561. http://dx.doi. org/10.1038/ngeo913.

Helz, G.R., Bura-Nakić, E., Mikac, N., Ciglenečki, I., 2011. New model for molybdenum behavior in euxinic waters. Chem. Geol. 284, 323-332.

Herbin, J.P., Fernandez-Martinez, J.L., Geyssant, J.R., El Albani, A., Deconinck, J.-F., Proust, J.-N., Colbeaux, J.-P., Vidier, J.P., 1995. Sequence stratigraphy of source rocks applied to the study of the Kimmeridgian/Tithonian in the Northwest European shelf (Dorset/UK, Yorkshire/UK and Boulonnais/France). Mar. Pet. Geol. 12, 177-194.

Hu, Y., Feng, D., Peckmann, J., Roberts, H.H., Chen, D., 2014. New insights into cerium anomalies and mechanisms of trace metal enrichment in authigenic carbonate from hydrocarbon seeps. Chem. Geol. 381, 55-66.

Huerta-Diaz, M.A., Morse, J.W., 1992. Pyritization of trace metals in anoxic marine sediments. Geochim. Cosmochim. Acta 56, 2681-2702.

Ingall, E.D., Van Cappellen, P., 1990. Relation between sedimentation rate and burial of organic phosphorus and organic carbon in marine sediments. Geochim. Cosmochim. Acta 54, 373-386. 
Ingall, E., Bustin, R.M., Van Cappellen, P., 1993. Influence of water-column anoxia on the burial and preservation of carbon and phosphorus in marine shales. Geochim. Cosmochim. Acta $57,303-316$.

Jarvis, I., Burnett, W.C., Nathan, Y., Almbaydin, F.S.M., Attia, A.K.M., Castro, L.N., Flicoteaux, R., Hilmy, M.E., Husain, V., Qutawnnah, A.A., Serjani, A., Zanin, Y.N., 1994. Phosphorite geochemistry: state of the art and environmental concerns. Eclogae Geol. Helv. $87,643-700$.

Jilbert, T., Slomp, C.P., 2013. Iron and manganese shuttles control the formation of authigenic phosphorus minerals in the euxinic basins of the Baltic Sea. Geochim. Cosmochim. Acta 107, 155-169.

Jones, R.W., 1984. Comparison of carbonate and shale source rocks. In: Palacas, G. (Ed.), Petroleum Geochemistry and Source Rock Potential of Carbonate Rocks. AAPG Studies in, Geology 18, pp. 163-180.

Kashiwabara, T., Takahashi, Y., Tanimizu, M., Usui, A., 2011. Molecular-scale mechanisms of distribution and isotopic fractionation of molybdenum between seawater and ferromanganese oxides. Geochim. Cosmochim. Acta 75, 5762-5784.

Krachler, R., von der Kammer, F., Jirsa, F., Süphandag, A., Krachler, R.F., Plessl, C., Vogt, M., Keppler, B.K., Hofmann, T., 2012. Nanoscale lignin particles as source of dissolved iron to the ocean. Glob. Biogeochem. Cycles 26, GB3024. http://dx.doi.org/10.1029/ $2012 \mathrm{~GB} 004294$.

Largeau, C., Derenne, S., Casadevall, E., Berkaloff, C., Corolleur, M., Lugardon, Raynaud, J.F., Connan, J., 1990. Occurrence and origin of "ultralaminar" structures in "amorphous" kerogens of various source rocks and oil shales. Advance in Organic Geochemistry 89 Org. Geochem. 16, 889-895.

Li, X.1., Shi, H.M., Xia, H.-Y., Zhou, Y.-P., Qiu, Y.W., 2014. Seasonal hypoxia and its potential forming mechanisms in the Mirs Bay, the Northern South China Sea. Cont. Shelf Res. 80, 1-7.

Lückge, A., Boussafir, M., Lallier-Verges, E., Littke, R., 1996. Comparative study of organic matter preservation in immature sediments along the continental margins of Peru and Oman. I: results of petrographical and bulk geochemical data. Org. Geochem. 24, 437-451. 
Lyons, T.W., Severmann, S., 2006. A critical look at iron paleoredox proxies based on new insights from modern euxinic marine basins. Geochim. Cosmochim. Acta 70, 5698-5722.

Martin, P., van der Loeff, M.R., Cassar, N., Vandromme, P., d'Ovidio, F., Stemmann, L., Rengarajan, R., Soares, M., González, H.E., Ebersbach, F., Lampitt, R.S., Sanders, R., Barnett, B.A., Smetacek, V., Naqvi, S.W.A., 2013. Iron fertilization enhanced net community production but not downward particle flux during the Southern Ocean iron fertilization experiment LOHAFEX. Glob. Biogeochem. Cycles 27, 871-881. http://dx.doi.org/10.1002/gbc.20077.

März, C., Poulton, S.W., Beckmann, B., Küster, K., Wagner, T., Kasten, S., 2008. Redox sensitivity of $\mathrm{P}$ cycling during marine black shale formation: Dynamics of sulfidic and anoxic, non-sulfidic bottom waters. Geochim. Cosmochim. Acta 72 (15), 3703-3717.

März, C., Stratmann, A., Matthiessen, J., Meinhardt, A.-K., Eckert, S., Schnetger, B., Vogt, C., Stein, R., Brumsack, H.-J., 2011a. Manganese-rich brown layers in Arctic Ocean sediments: composition, formation mechanisms, and diagenetic overprint. Geochim. Cosmochim. Acta 75, 7668-7687.

März, C., Vogt, C., Schnetger, B., Brumsack, H.-J., 2011b. Variable Eocene-Miocene sedimentation processes and bottom water redox conditions in the Central Arctic Ocean (IODP Expedition 302). Earth Planet. Sci. Lett. 310, 526-537.

März, C., Poulton, S.W., Wagner, T., Schnetger, B., Brumsack, H.-J., 2014. Phosphorus burial and diagenesis in the central Bering Sea (Bowers Ridge, IODP Site U1341): perspectives on the marine P cycle. Chem. Geol. 363, 270-282.

McLennan, S.M., 2001. Relationships between the trace element composition of sedimentary rocks and upper continental crust. Geochem. Geophys. Geosyst. 2 (2000GC000109).

Meyers, S.R., 2007. Production and preservation of organic matter: the significance of iron. Paleoceanography 22, PA4211. http://dx.doi.org/10.1029/2006PA001332.

Meyers, S.R., Sageman, B.B., Lyons, T.W., 2005. Organic carbon burial rate and the molybdenum proxy: theoretical framework and the application to Cenomanian-Turonian oceanic anoxic event 2. Paleoceanography 20, PA2002. http://dx.doi.org/10.1029/ 2004PA001068.

Minami, H., Kato, Y., 1997. Remobilization of arsenic in sub-oxic sediments from seafloor of the continental margin. J. Oceanogr. 53, 553-562. 
Mongenot, T., Boussafir, M., Derenne, S., Lallier-Vergès, E., Largeau, C., Tribovillard, N., 1997. Sulphur-rich organic matter from Bituminous Laminites of Orbagnoux (France, upper Kimmeridgian) — the role of early vulcanization. Bull. Soc. Geol. Fr. 168 (3), 331-341.

Mongenot, T., Derenne, S., Largeau, C., Tribovillard, N., Lallier-Vergès, E., Dessort, D., Connan, J., 1999. Spectroscopic, kinetic and pryolytic studies of kerogen from the dark parallel laminae facies of the sulphur-rich Orbagnoux deposit (Upper Kimmeridgian, Jura). Org. Geochem. 30, 39-56.

Neumann, T., Scholz, F., Kramar, U., Ostermaier, M., Rausch, N., Berner, Z., 2013. Arsenic in framboidal pyrite from recent sediments of a shallow water lagoon of the Baltic Sea. Sedimentology http://dx.doi.org/10.1111/sed.12031.

O'Day, P., 2006. Chemistry and mineralogy of arsenic. Elements 2, 77-83.

Oehler, J.H., 1984. Carbonate source rock in the Jurassic Smackover trend of Mississippi, Alabama, and Florida. In: Palacas, G. (Ed.), Petroleum Geochemistry and Source Rock Potential of Carbonate Rocks. AAPG Studies in Geology 18, pp. 63-70.

Owens, J.D., Lyons, T.W., Li, X., Macleod, K.G., Gordon, G., Kuypers, M.M.M., Anbar, A., Kuhnt, W., Severmann, S., 2012. Iron isotope and trace metal records of iron cycling in the proto-North Atlantic during the Cenomanian-Turonian oceanic anoxic event (OAE-2). Paleoceanography 27, PA3223. http://dx.doi.org/10.1029/2012PA002328.

Palacas, G.J., Anders, D.E., King, J.D., 1984. South Florida basin. Prime example of carbonate source rock of petroleum. In: Palacas, G. (Ed.), Petroleum Geochemistry and Source

Rock Potential of Carbonate Rocks. AAPG Studies in Geology 18, pp. 71-96.

Piper, D.Z., Perkins, R.B., 2004. A modern vs. Permian black shale - the hydrography, primary productivity, and water-column chemistry of deposition. Chem. Geol. 206, 177-197. Piper, D.Z., Perkins, R.B., 2014. Geochemistry of a marine phosphate deposit: a signpost to phosphogenesis. In: Scott, S.D. (Ed.), Geochemistry of Mineral Deposits, second edition. Treatise on Geochemistry vol. 13, pp. 293-312.

Poulton, S.W., Canfield, D.E., 2005. Development of a sequential extraction procedure for iron: implications for iron partitioning in continentally derived particulates. Chem. Geol. 214, 209-221. 
Poulton, S.W., Canfield, D.E., 2011. Ferruginous conditions: a dominant feature in the ocean through Earth's history. Elements 7, 107-112.

Poulton, S.W., Raiswell, R., 2002. The low-temperature geochemical cycle of iron: from continental fluxes to marine sediment deposition. Am. J. Sci. 302, 774-805.

Proust, J.-N., 1994. Notions élémentaires de stratigraphie séquentielle illustrées par un exemple. Ann. Soc. Géol. Nord 3 (II), 5-25.

Proust, J.-N., Deconinck, J.-F., Geyssant, J.R., Herbin, J.-P., Vidier, J.P., 1993. Nouvelles données sédimentologiques dans le Kimméridgien et le Tithonien du Boulonnais (France). CR Acad. Sci. Paris 316 (II), 363-369.

Proust, J.-N., Deconinck, J.-F., Geyssant, J.R., Herbin, J.-P., Vidier, J.P., 1995. Sequence analytical approach to the Upper Kimmeridgian-Lower Tithonian storm-dominated ramp deposits of the Boulonnais (Northern France). A landward time-equivalent to offshore marine source rocks. Geol. Rundsch. 84, 255-271.

Raiswell, R., Canfield, D.E., 1996. Rates of reaction between silicate iron and dissolved sulfide in Peru Margin sediments. Geochim. Cosmochim. Acta 60, 2777-2787.

Raiswell, R., Canfield, D.E., 2012. The iron biogeochemical cycle past and present. Geochem. Perspect. 1, 1-186.

Ramanampisoa, L., Bertrand, P., Disnar, J.R., Lallier-Vergès, E., Pradier, B., Tribovillard, N.P., 1992. Etude à haute résolution d'un cycle du carbone organique des argiles du Kimméridgien du Yorkshire (G.-B.): résultats préliminaires de géochimie et de pétrographie organique. CR Acad. Sci. Paris II 314, 1493-1498.

Ramdani, A., 1996. Les paramètres qui contrôlent la sédimentation cyclique de la Kimmeridge Clay Formation dans le bassin de Clevelan (Yorkshire, Grande Bretagne) comparaison avec le Boulonnais (France). $\mathrm{PhD}$ thesis, Paris XI-Orsay University, unpublished.

Reed, D.C., Slomp, C.P., Gustafsson, B.G., 2011. Sedimentary phosphorus dynamics and the evolution of bottom-water hypoxia: a coupled benthic-pelagic model of a coastal system. Limnol. Oceanogr. 56, 1075-1092.

Reimers, C.E., Ruttenberg, K.C., Canfield, D.E., Christiansen, M.B., Martin, J.B., 1996. Porewater $\mathrm{pH}$ and authigenic phases formed in the uppermost sediments of the Santa Barbara Basin. Geochim. Cosmochim. Acta 60, 4037-4057. 
Rickard, D., 2012. Sulfidic sediments and sedimentary rock. Developments in Sedimentology 65. Elsevier (801 p.).

Sageman, B.B., Lyons, T.W., 2003. Geochemistry of fine-grained sediments and sedimentary rocks. In: Holland, H.D., Turekian, K.K. (Eds.), Treatise on Geochemistry. vol. 7. Elsevier, pp. $115-158$.

Sarret, G., Mongenot, T., Connan, J., Derenne, S., Kasrai, M., Bancroft, G.M., Largeau, C., 2002. Sulfur speciation in kerogens of the Orbagnoux deposit (Upper Kimmeridgian, Jura) by XANES spectroscopy and pyrolysis. Org. Geochem. 33, 877-895.

Schenau, S.J., Reichart, G.J., de Lange, De Lange, G.J., 2005. Phosphorus burial as a function of paleoproductivity and redox conditions in Arabian Sea sediments. Geochim. Cosmochim. Acta 69, 919-931.

Scholz, F., Hensen, C., Noffke, A., Rohde, A., Liebetrau, V., Wallmann, K., 2011. Early diagenesis of redox-sensitive trace metals in the Peru upwelling area - response to ENSOrelated oxygen fluctuations in the water column. Geochim. Cosmochim. Acta 75, 7257-7276.

Scholz, F., McManus, J., Sommer, S., 2013. The manganese and iron shuttle in a modern euxinic basin and implications for molybdenum cycling at euxinic ocean margins. Chem. Geol. 335, 56-68.

Scholz, F., Severmann, S., McManus, J., Hensen, C., 2014. Beyond the Black Sea paradigm: the sedimentary fingerprint of an open-marine iron shuttle. Geochim. Cosmochim. Acta 127, $368-380$.

Scott, C., Lyons, T.W., 2012. Contrasting molybdenum cycling and isotopic properties in euxinic versus non-euxinic sediments and sedimentary: refining the paleoproxies. Chem. Geol. 324-325, 19-27.

Severmann, S., McManus, J., Berelson, W.M., Hammond, D.E., 2010. The continental shelf benthic iron flux and its isotope composition. Geochim. Cosmochim. Acta 74, 3984-4004.

Shigemitsu, M., Nishioka, J., Watanabe, Y.W., Yamanaka, Y., Nakatsuka, T., Volkov, Y.N., 2013. Fe/Al ratios of suspended particulate matter from intermediate water in the Okhotsk Sea: implications for long-distance lateral transport of particulate Fe. Mar. Chem. 157, 41-48. Slomp, C.P., Van Cappellen, P., 2007. The global marine phosphorus cycle: sensitivity to oceanic circulation. Biogeosciences 4, 155-171. 
Slomp, C.P., Van der Gaast, S.J., Van Raaphorst, W., 1996. Phosphorus binding by poorly crystalline iron oxides in North Sea sediments. Mar. Chem. 52, 55-73.

Soudry, D., 2000. Carbonate-phosphate competition in the Negev phosphorites (southern Israel): a microstructural study. In: Glenn, C.R., Prévôt-Lucas, L., Lucas, J. (Eds.), Marine authigenesis: from global to microbial. SEPM Spec. Publ. 66, pp. 415-426.

Stein, M., Arnaud-Vanneau, A., Adatte, T., Fleitmann, D., Spangenberg, J.E., Föllmi, K.B., 2012. Paleoenvironmental and paleoecological change on the northern Tethyan carbonate platform during the late Barremian-earliest Aptian. Sedimentology 59, 939-963.

Sullivan, K.A., Aller, R.C., 1996. Diagenetic cycling of arsenic in Amazon shelf sediments. Geochim. Cosmochim. Acta 60, 1465-1477.

Taguchi, K., Mori, K., 1992. The distribution and generation of hydrocarbons in carbonate source rocks. In: Whelan, J.K., Farrington, J.W. (Eds.), Organic Matter. Production, Accumulation and Preservation in Recent and Ancient Sediments. Columbia University Press, New York, pp. 487-515.

Taylor, K.G., Konhauser, K.O., 2011. Iron in Earth surface systems. Elements 7, 1-144.

Taylor, K.G., Macquaker, J.H.S., 2011. Iron minerals in marine sediments record chemical environments. Elements 7, 113-118.

Taylor, S.R., McLennan, S.M., 1985. The Continental Crust: Its Composition and Evolution. Blackwell, Oxford (312 pp.).

Taylor, S.P., Sellwood, B.W., Gallois, R.W., Chambers, M.H., 2001. A sequence stratigraphy of the Kimmeridgian and Bolonian stages (Late Jurassic): Wessex-Weald Basin, southern England. J. Geol. Soc. 158, 179-192.

Tegelaar, E.W., de Leeuw, J.W., Derenne, S., Largeau, C., 1989. A reappraisal of kerogen formation. Geochim. Cosmochim. Acta 53, 3103-3106.

Trappe, J., 1998. Phanerozoic phosphorite depositional systems. Lecture Notes in Earth Sciences 76. Springer (316 p.).

Tribovillard, N., Desprairies, A., Lallier-Vergès, L., Bertrand, P., 1994. Sulfur incorporation of lipidic organic matter in reactive-iron deficient environments: a possible enhancement for the storage of hydrogen-rich organic matter. CR Acad. Sci. Paris 319, 1199-1206. 
Tribovillard, N., Bialkowski, A., Tyson, R.V., Vergès, E., Deconinck, J.-F., 2001. Organic facies and sea level variation in the Late Kimmeridgian of the Boulonnais area (northernmost France). Mar. Pet. Geol. 18, 371-389.

Tribovillard, N., Averbuch, O., Bialkowski, A., Deconninck, J.-F., 2002. The influence of the early diagenesis of marine organic matter on the magnetic-susceptibility signal of sedimentary rock. Bull. Soc. Geol. Fr. 173, 295-306.

Tribovillard, N., Averbuch, O., Riboulleau, A., 2004a. Influence of marine organic-matter diagenesis on magnetic susceptibility of sedimentary rocks: the sulphide pathway. Ann. Soc. Géol. Nord t.11 (2è série), 57-67.

Tribovillard, N., Riboulleau, A., Lyons, T., Baudin, F., 2004b. Enhanced trapping of molybdenum by sulfurized organic matter of marine origin as recorded by various Mesozoic formations. Chem. Geol. 213, 385-401.

Tribovillard, N., Ramdani, A., Trentesaux, A., 2005. Controls on organic accumulation in Late Jurassic shales of Northwestern Europe as inferred from trace-metal geochemistry. In: Harris, N. (Ed.), The Deposition of Organic-Carbon-Rich Sediments: Models, Mechanisms, and Consequences. SEPM Special Publication 82, pp. 145-164.

Tribovillard, N., Bout-Roumazeilles, V., Algeo, T.J., Lyons, T.W., Sionneau, T., MonteroSerrano, J.C., Riboulleau, A., Baudin, F., 2008a. Paleodepositional conditions in the Orca Basin as inferred from organic matter and trace metal contents. Mar. Geol. 254, 62-72.

Tribovillard, N., Lyons, T.W., Riboulleau, A., Bout-Roumazeilles, V., 2008b. A possible capture of molybdenum during early diagenesis of dysoxic sediments. Bull. Soc. Geol. Fr. $179,3-12$.

Tribovillard, N., Bout-Roumazeilles, V., Riboulleau, A., Baudin, F., Danelian, T., Riquier, L., 2011. Transfer of germanium to marine sediments: insights from its accumulation in radiolarites and authigenic capture under reducing conditions. Some examples through geological ages. Chem. Geol. 282, 120-130.

Tribovillard, N., Algeo, T.J., Baudin, F., Riboulleau, A., 2012a. Analysis of marine environmental conditions based on molybdenum-uranium covariation-applications to Mesozoic paleoceanography. Chem. Geol. 324-325, 46-58. 
Tribovillard, N., Sansjofre, P., Ader, M., Trentesaux, A., Averbuch, O., Barbecot, F., 2012b. Early diagenetic carbonate bed formation at the sediment-water interface triggered by synsedimentary faults. Chem. Geol. 300 (301), 1-13.

Tribovillard, N., Armynot du Châtelet, E., Gay, A., Barbecot, F., Sansjofre, P., Potdevin, J.L., 2013. Geochemistry of cold seepage-impacted sediments: Per-ascensum or perdescensum trace metal enrichment? Chem. Geol. 340, 1-12.

Tyson, R.V., 1995. Sedimentary Organic Matter: Organic Facies and Palynofacies. Chapman \& Hall, London (615 p.).

Van Cappellen, P., Ingall, E.D., 1994. Benthic phosphorus regeneration, net primary production and ocean anoxia: a model of the coupled marine biogeochemical cycles of carbon and phosphorus. Paleoceanography 9, 677-692.

Van der Weijden, C.H., 2002. Pitfalls of normalization of marine geochemical data using a common divisor. Mar. Geol. 184, 167-187.

Vandenbroucke, M., Largeau, C., 2007. Kerogen origin, evolution and structure. Org. Geochem. 38, 719-833.

Vaughan, D.J., 2006. Arsenic. Elements 2, 71-75.

Wang, Y., van Cappellen, P., 1996. A multicomponent reactive transport model of early diagenesis: application to redox cycling in coastal marine sediments. Geochim. Cosmochim. Acta 60, 2993-3014.

Wignall, P.B., 1991. Test of the concepts of sequence stratigraphy in the Kimmeridgian (Late Jurassic) of England and northern France. Mar. Pet. Geol. 8, 430-441.

Wignall, P.B., Newton, R., 2001. Black shales on the basin margin: a model based on examples from the Upper Jurassic of the Boulonnais, northern France. Sediment. Geol. 144, $335-356$.

Wijsman, J.W.M., Middleburg, J.J., Heip, C.H.R., 2001. Reactive iron in Black Sea sediments: implications for iron cycling. Mar. Geol. 172, 167-180.

Williams, C.J., Hesselbo, S.P., Jenkyns, H.C., Morgans-Bell, H.S., 2001. Quartz silt in mudrocks as a key to sequence stratigraphy (Kimmeridge Clay Formation, Late Jurassic, Wessex Basin, UK). Terra Nova 13, 449-455. 
Zaback, D.A., Pratt, L.M., Hayes, J.M., 1993. Transport and reduction of sulphate and immobilisation of sulphide in marine black shales. Geology 21, 141-144. 
Figure captions

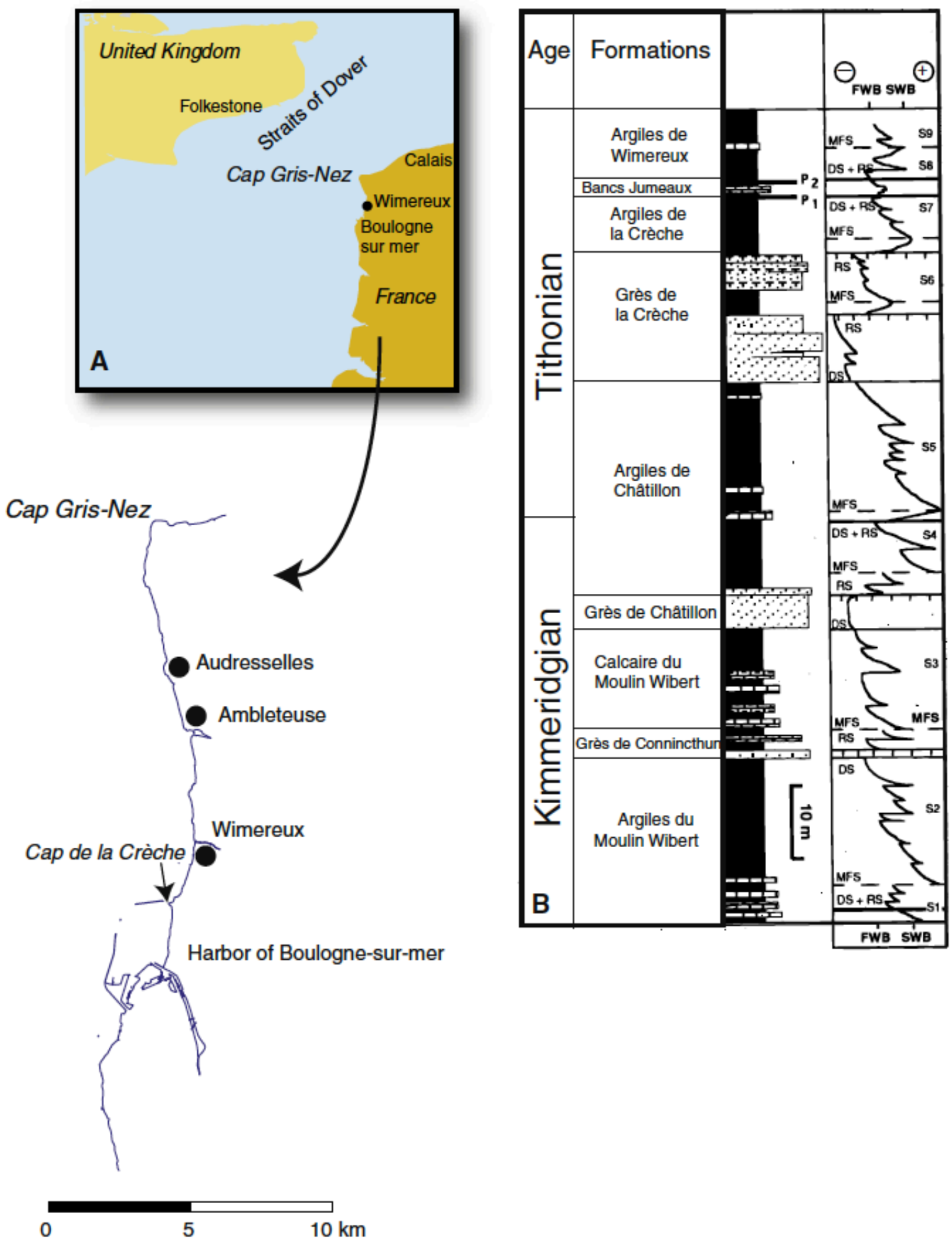

Fig. 1. Maps showing the location of the study area, between the Gris Nez Cape and the city of Wimereux. Right-hand side: simplified lithostratigraphic $\log$ of the Late Jurassic formations cropping alongshore the Boulonnais (after Deconinck et al., 1996).FWB and SWB stand for fair-weather wave base and storm-weather wave base, respectively. P1 and P2 stand for the two horizons rich in phosphatized shells. 


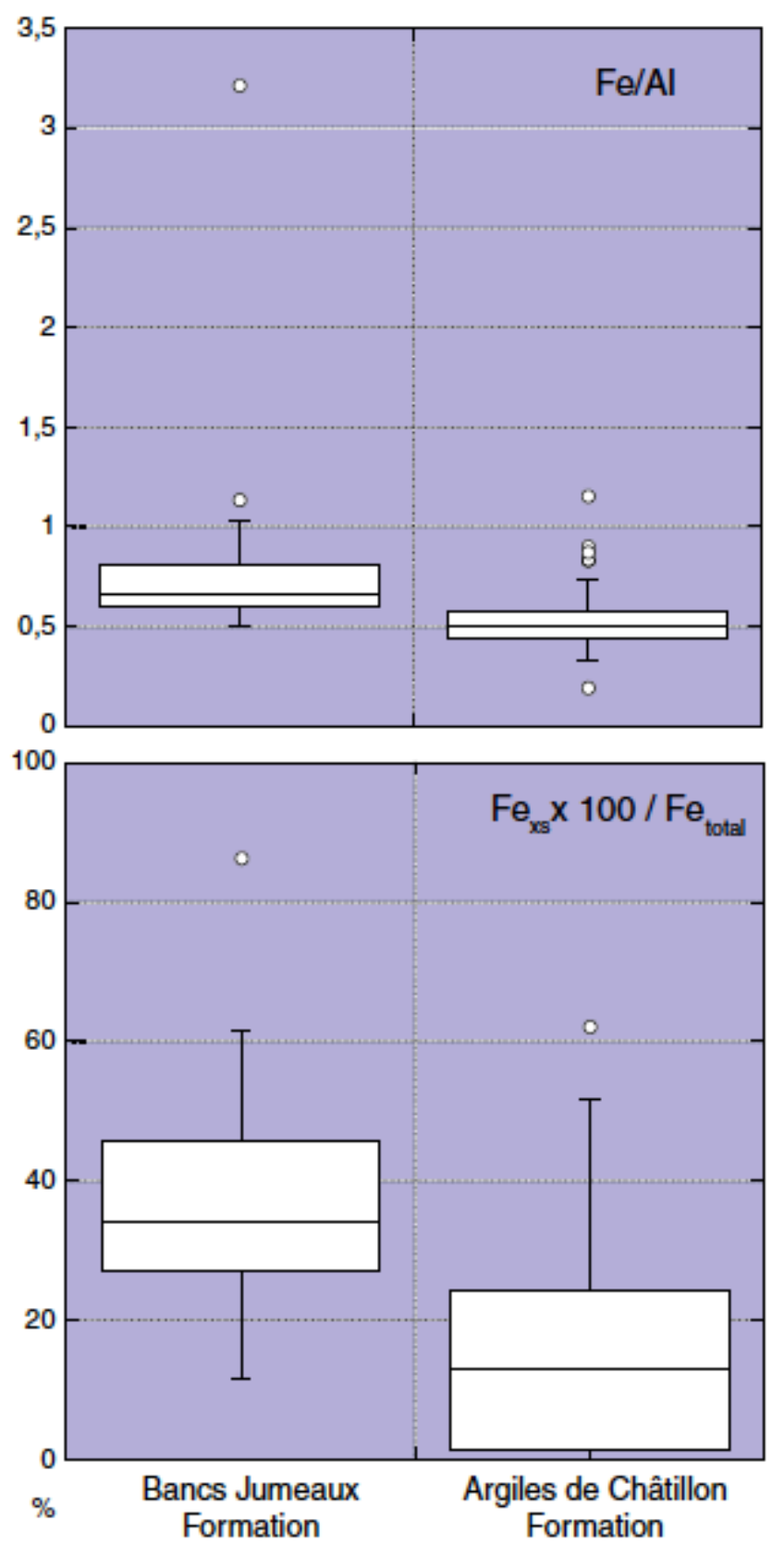

Fig. 2. Iron data for the two formations studied: Fe/Al ratio and proportion of $F_{\text {exs }}$ within total Fe content of the samples. $\mathrm{F}_{\mathrm{exs}}$ is an approximation of the authigenic Fe content. Fe $_{\text {detrital }}=$ $[\mathrm{Al}]_{\text {sample }} x[\mathrm{Fe}] /[\mathrm{Al}]_{\text {upper crust, }}$ with $[\mathrm{Fe}] /[\mathrm{Al}]_{\text {upper crust }}=0.44 \quad$ (McLennan, 2001). 


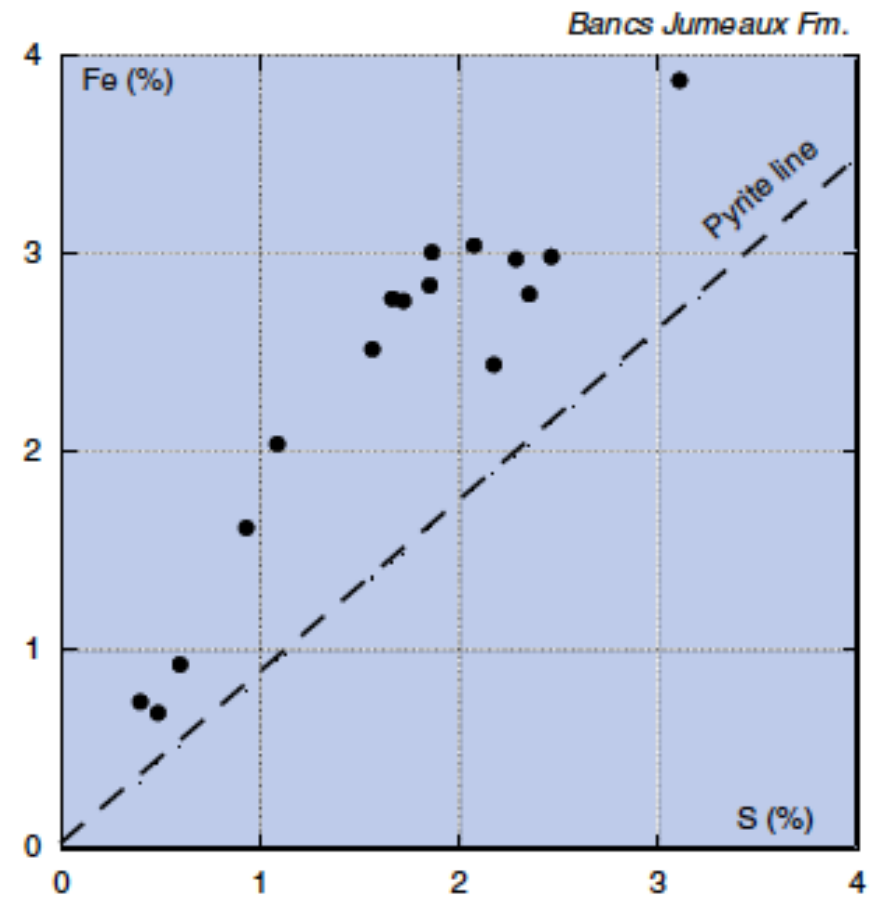

Fig. 3. Total sulfur concentration opposed to total iron concentrations, showing the stoichiometric line for pyrite, for the Bancs Jumeaux samples. The fact that iron plots above the pyrite line suggests that pyrite formation was limited by sulfate abundance, which left iron in excess. 
Bancs Jumeaux Formation
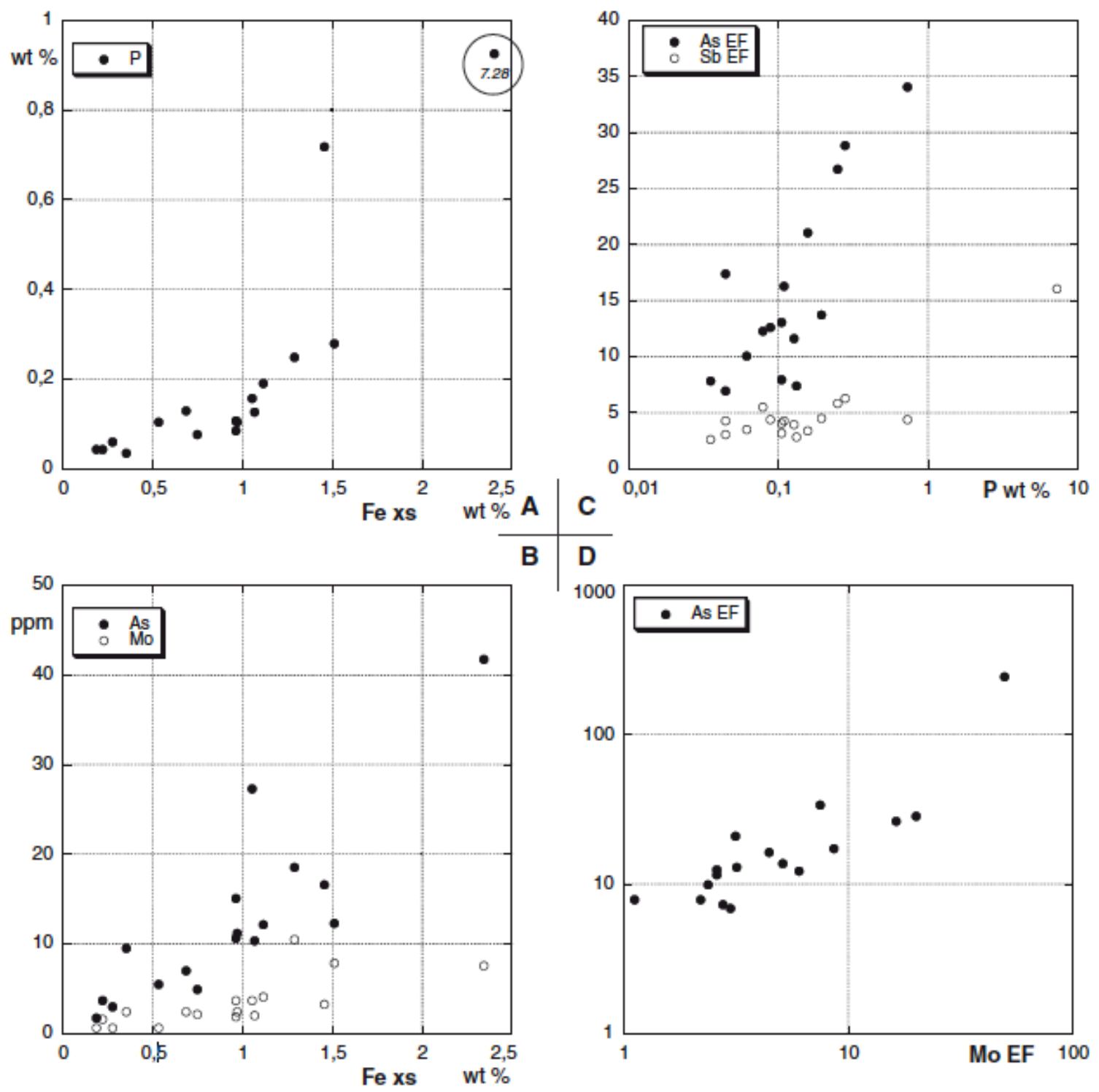

Fig. 4. Various crossplots illustrating the correlations between element abundance for the Bancs Jumeaux samples. EF stands for enrichment factor. A: $F_{\text {exs }}$ vs. P; B: $F_{\text {exs }}$ vs. As and Mo; C: P vs. As-EF and Sb-EF; D: and Mo-EF vs. As-EF. 


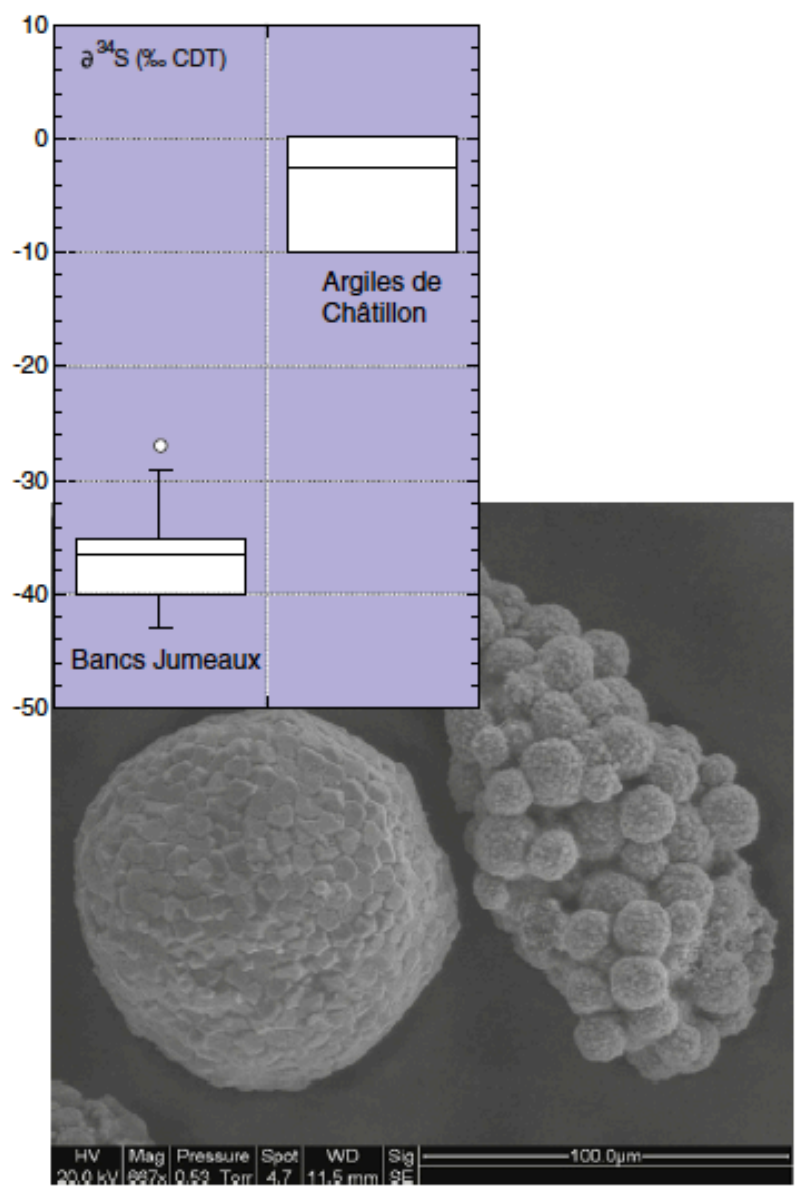

Fig. 5. Stable sulfur isotope data $\left(\delta^{34} \mathrm{~S} \% \mathrm{CDT}\right)$ for the two formations compared in this study. Inserted electronic image illustrates the two pyrite-framboid morphologies most frequently observed in the samples. 


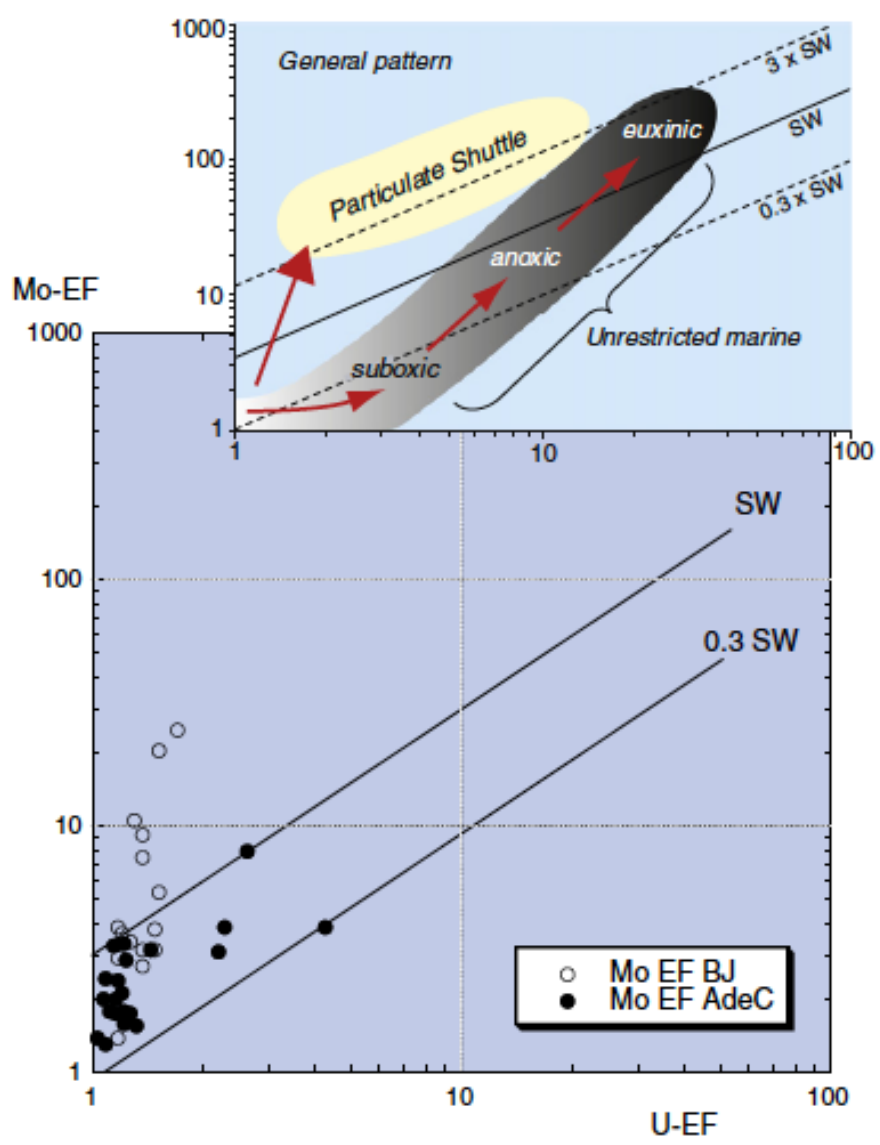

Fig. 6. Crossplot opposing the respective enrichment factors of $U$ and Mo for the two formations studied, as designed by Algeo and Tribovillard (2009) to derive paleoenvironmental information. BJ stands for Bancs Jumeaux Fm., AdeC stands for Argiles de Châtillon Fm. 
Table 1

Rock Eval data of the two formations studied (from Tribovillard et al., 2008a).

\begin{tabular}{llll}
\hline & $\begin{array}{l}\text { TOC } \\
(\text { wt. })\end{array}$ & $\begin{array}{l}\text { HI } \\
(\mathrm{mg} \mathrm{HC} \text { per g TOC) }\end{array}$ & $\begin{array}{l}\text { Tmax } \\
\left({ }^{\circ} \mathrm{C}\right)\end{array}$ \\
\hline Argiles de Châtillon Fm. & $1-8$ & $80-556$ & $\begin{array}{l}411-453 \\
(\text { mean 423) }\end{array}$ \\
Bancs Jumeaux Fm. & $1-2$ & $150-360$ & $420-430$ \\
\hline
\end{tabular}

Table 2

Compared clay-mineral contents of the two formations studied.

\begin{tabular}{lcc}
\hline Clay minerals & Bancs Jumeaux Fm. & Argiles de Chåtillon Fm. \\
\hline Illite-smectite mixed-layers & $30-84 \%$ (mean $67 \%$ ) & $30-50 \%$ (mean 37\%) \\
Illite & $14-50 \%$ (mean $27 \%$ ) & $30-47 \%$ (mean 41\%) \\
Chlorite & $0-2 \%$ (mean $1 \%)$ & $4-6 \%$ (mean 5\%) \\
Kaolinite & $1-19 \%($ mean $5 \%)$ & $15-19 \%$ (mean 17\%) \\
\hline
\end{tabular}


Table 3

Iron data for the two formations studied: $\mathrm{Fe} / \mathrm{Al}$ ratio and proportion of $\mathrm{F}_{\mathrm{exs}}$ within total $\mathrm{Fe}$ content of the samples.

\begin{tabular}{|c|c|c|c|c|c|c|c|}
\hline \multicolumn{2}{|c|}{ Bancs Jumeaux Fm. } & \multicolumn{6}{|c|}{ Argiles de Châtillon Formation } \\
\hline \multirow[t]{2}{*}{$\mathrm{Fe} / \mathrm{Al}$} & \multirow[t]{2}{*}{$\% \mathrm{Fe}_{\mathrm{xs} /} / \mathrm{Fe}_{\mathrm{tatal}}$} & \multicolumn{2}{|c|}{ Sample set 1} & \multicolumn{2}{|c|}{ Sample set 2} & \multicolumn{2}{|c|}{ Sample set 3} \\
\hline & & $\mathrm{Fe} / \mathrm{Al}$ & $\approx \mathrm{Fe}_{\mathrm{xs}} / \mathrm{Fe}_{\text {total }}$ & $\mathrm{Fe} / \mathrm{Al}$ & $\% \mathrm{Fe}_{\mathrm{x} s} / \mathrm{Fe}_{\text {total }}$ & $\mathrm{Fe} / \mathrm{Al}$ & $\% \mathrm{Fe}_{\mathrm{xs}} / \mathrm{Fe}_{\mathrm{mat}}$ \\
\hline 0.59 & 26 & 0.84 & 48 & 0.74 & 40.8 & 0.43 & 0 \\
\hline 0.80 & 46 & 0.90 & 52 & 0.65 & 32.8 & 0.42 & 0 \\
\hline 1.14 & 62 & 0.51 & 14 & 0.59 & 25.9 & 0.37 & 0 \\
\hline 1.03 & 58 & 0.52 & 16 & 0.87 & 50.3 & 0.46 & 5 \\
\hline 0.61 & 29 & 0.58 & 24 & 0.53 & 18.5 & 0.44 & 1 \\
\hline 0.60 & 27 & 0.60 & 28 & 0.57 & 23.8 & 0.34 & 0 \\
\hline 0.68 & 36 & 0.84 & 48 & 0.55 & 20.5 & 0.40 & 0 \\
\hline 0.57 & 24 & 0.48 & 9 & 0.61 & 28.5 & 0.41 & 0 \\
\hline 0.58 & 25 & 0.48 & 9 & 0.64 & 31.7 & 0.41 & 0 \\
\hline 0.49 & 12 & 0.51 & 14 & 0.59 & 25.9 & 0.44 & 1 \\
\hline 0.63 & 31 & 0.46 & 6 & 0.52 & 15.8 & 0.40 & 0 \\
\hline 0.80 & 46 & 0.67 & 35 & 0.58 & 24.4 & 0.47 & 8 \\
\hline 0.64 & 32 & 0.43 & 0 & 0.57 & 23.7 & 0.46 & 6 \\
\hline 0.67 & 35 & 0.50 & 12 & 0.57 & 23.7 & 0.46 & 6 \\
\hline 0.66 & 34 & 0.50 & 14 & 0.60 & 27.8 & 0.49 & 12 \\
\hline 0.66 & 34 & 0.53 & 18 & 0.48 & 9.3 & 0.45 & 3 \\
\hline \multirow[t]{6}{*}{3.22} & 86 & 0.45 & 3 & 0.55 & 21.2 & 0.41 & 0 \\
\hline & & 0.47 & 7 & 0.49 & 11.7 & 0.42 & 0 \\
\hline & & 0.42 & 0 & 1.15 & 62.3 & 0.48 & 9 \\
\hline & & 0.49 & 11 & 0.54 & 19.8 & 0.19 & 0 \\
\hline & & 0.54 & 20 & & & 0.33 & 0 \\
\hline & & 0.56 & 22 & & & & \\
\hline
\end{tabular}


Table 4

Geochemical data (major and trace elements) of the sample set from the Argiles de Chattillon Fm. bL.D. means below limit of detection. See calculation of excess iron $\left(\mathrm{F}_{\mathrm{exs}}\right)$ in text.

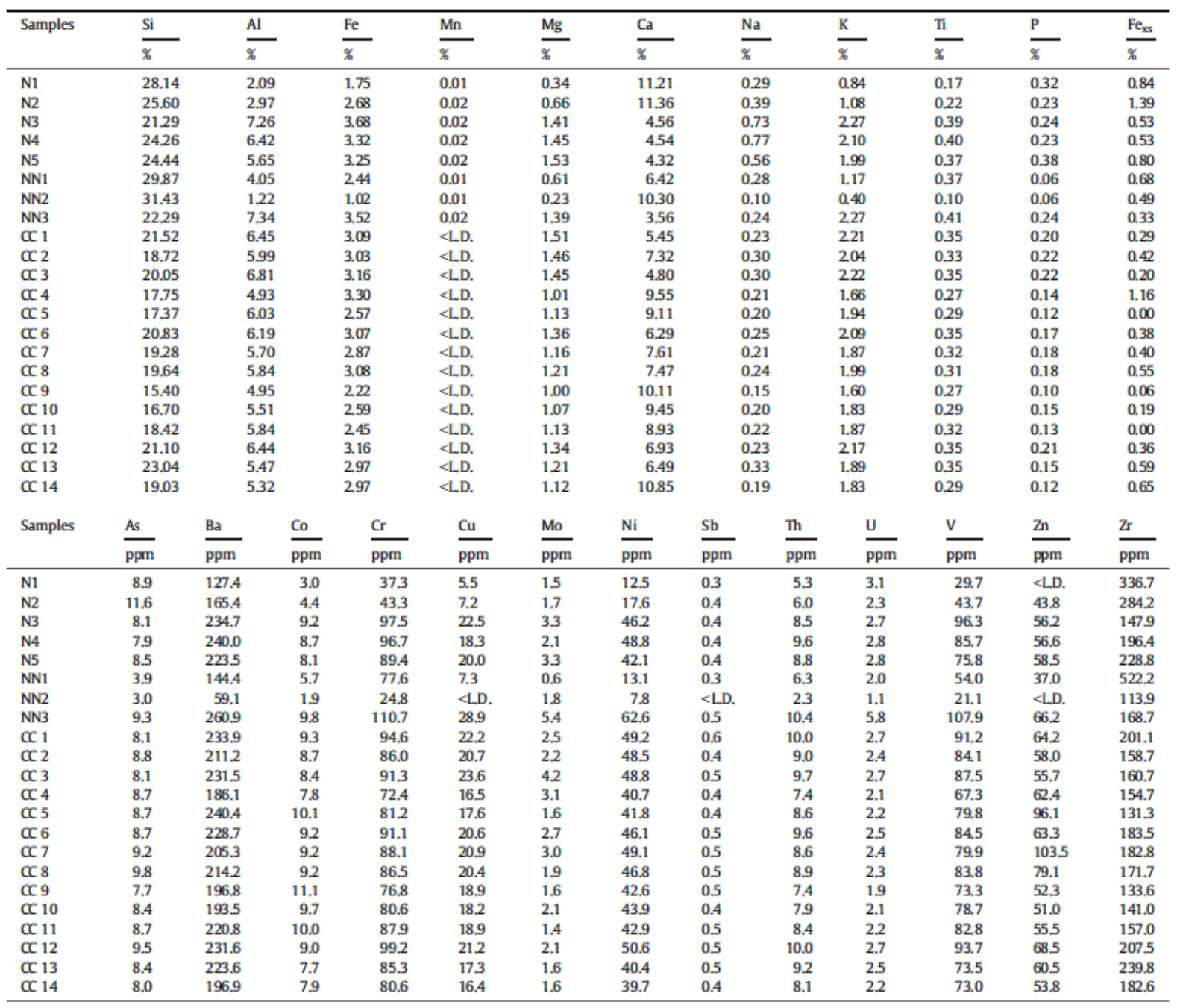


Table 5

Geochemical data (Al-normalized concentrations and enrichment factors) of the sample set from the Argiles de Châtillon Fm. EF stands for enrichment factor (see text). bL.D. means below limit of detection.

\begin{tabular}{|c|c|c|c|c|c|c|c|c|c|c|c|c|c|}
\hline \multirow[t]{2}{*}{ Samples } & \multirow{2}{*}{$\frac{\mathrm{Si} / \mathrm{Al}}{\%: \%}$} & \multirow{2}{*}{$\frac{\mathrm{Fe} / \mathrm{Al}}{\%: \%}$} & \multirow{2}{*}{$\frac{\mathrm{Mn} / \mathrm{Al}}{\not{\%}: \%}$} & \multirow{2}{*}{$\frac{\mathrm{Mg} / \mathrm{Al}}{\%: \%}$} & \multirow{2}{*}{$\frac{\mathrm{Ca} / \mathrm{Al}}{\% \%}$} & \multirow{2}{*}{$\frac{\mathrm{Na} / \mathrm{Al}}{\%: \%}$} & $\mathrm{~K} / \mathrm{Al}$ & $\mathrm{Ti} / \mathrm{Al}$ & $\mathrm{P} / \mathrm{Al}$ & $\mathrm{Ba} / \mathrm{Al}$ & $\mathrm{Ni} / \mathrm{Al}$ & $\mathrm{Cu} / \mathrm{Al}$ & $\mathrm{Zn} / \mathrm{Al}$ \\
\hline & & & & & & & \%:\% & $\%: \%$ & \%:\% & $\overline{\mathrm{ppm}: \%}$ & $\overline{\mathrm{ppm}: \%}$ & $\overline{\mathrm{ppm}: \%}$ & $\overline{\mathrm{ppm} \%}$ \\
\hline N1 & 13.46 & 0.84 & 0.01 & 0.16 & 5.36 & 0.14 & 0.40 & 0.08 & 0.15 & 60.9 & 6.0 & 26 & $<\mathrm{LD}$. \\
\hline N2 & 8.61 & 0.90 & 0.01 & 0.22 & 3.82 & 0.13 & 0.36 & 0.07 & 0.08 & 55.7 & 5.9 & 24 & 14.8 \\
\hline N3 & 2.93 & 0.51 & 0.00 & 0.19 & 0.63 & 0.10 & 0.31 & 0.05 & 0.03 & 32.3 & 6.4 & 3.1 & 7.7 \\
\hline N4 & 3.78 & 0.52 & 0.00 & 0.23 & 0.71 & 0.12 & 0.33 & 0.06 & 0.04 & 37.4 & 7.6 & 28 & 8.8 \\
\hline N5 & 4.33 & 0.58 & 0.00 & 0.27 & 0.76 & 0.10 & 0.35 & 0.07 & 0.07 & 39.6 & 7.5 & 3.5 & 10.4 \\
\hline NN1 & 7.37 & 0.60 & 0.00 & 0.15 & 1.58 & 0.07 & 0.29 & 0.09 & 0.01 & 35.6 & 3.2 & 1.8 & 9.1 \\
\hline NN2 & 25.72 & 0.84 & 0.01 & 0.19 & 8.43 & 0.08 & 0.33 & 0.08 & 0.05 & 48.4 & 6.3 & $<$ L.D. & L.D. \\
\hline NN3 & 3.04 & 0.48 & 0.00 & 0.19 & 0.49 & 0.03 & 0.31 & 0.06 & 0.03 & 35.6 & 8.5 & 3.9 & 9.0 \\
\hline $\mathrm{CC} 1$ & 3.34 & 0.48 & $<$ LD. & 0.23 & 0.84 & 0.04 & 0.34 & 0.05 & 0.03 & 36.3 & 7.6 & 3.4 & 9.9 \\
\hline $\mathrm{CC} 2$ & 3.13 & 0.51 & $<$ L.D. & 0.24 & 1.22 & 0.05 & 0.34 & 0.06 & 0.04 & 35.3 & 8.1 & 3.5 & 9.7 \\
\hline $\mathrm{CC} 3$ & 2.95 & 0.46 & $<$ L.D. & 0.21 & 0.70 & 0.04 & 0.33 & 0.05 & 0.03 & 34.0 & 7.2 & 3.5 & 8.2 \\
\hline CC 4 & 3.60 & 0.67 & $<$ LD. & 0.21 & 1.94 & 0.04 & 0.34 & 0.05 & 0.03 & 37.8 & 8.3 & 3.3 & 12.7 \\
\hline CC 5 & 2.88 & 0.43 & $<$ L.D. & 0.19 & 1.51 & 0.03 & 0.32 & 0.05 & 0.02 & 39.9 & 6.9 & 2.9 & 15.9 \\
\hline CC 6 & 3.36 & 0.50 & $<$ L.D. & 0.22 & 1.02 & 0.04 & 0.34 & 0.06 & 0.03 & 36.9 & 7.4 & 3.3 & 10.2 \\
\hline CC 7 & 3.38 & 0.50 & $<$ L.D. & 0.20 & 1.34 & 0.04 & 0.33 & 0.06 & 0.03 & 36.0 & 8.6 & 3.7 & 18.2 \\
\hline cC 8 & 3.36 & 0.53 & $<$ L.D. & 0.21 & 1.28 & 0.04 & 0.34 & 0.05 & 0.03 & 36.7 & 8.0 & 3.5 & 13.5 \\
\hline CC 9 & 3.11 & 0.45 & $<$ L.D. & 0.20 & 2.04 & 0.03 & 0.32 & 0.05 & 0.02 & 39.7 & 8.6 & 3.8 & 10.6 \\
\hline CC 10 & 3.03 & 0.47 & $<$ L.D. & 0.19 & 1.71 & 0.04 & 0.33 & 0.05 & 0.03 & 35.1 & 8.0 & 3.3 & 9.3 \\
\hline CC 11 & 3.15 & 0.42 & $<$ L.D. & 0.19 & 1.53 & 0.04 & 0.32 & 0.05 & 0.02 & 37.8 & 7.3 & 3.2 & 9.5 \\
\hline $\mathrm{CC} 12$ & 3.28 & 0.49 & $<$ L.D. & 0.21 & 1.08 & 0.04 & 0.34 & 0.05 & 0.03 & 36.0 & 7.9 & 3.3 & 10.6 \\
\hline $\mathrm{CC} 13$ & 4.21 & 0.54 & $<$ L.D. & 0.22 & 1.19 & 0.06 & 0.35 & 0.06 & 0.03 & 40.9 & 7.4 & 3.2 & 11.1 \\
\hline CC 14 & 3.58 & 0.56 & <L. & 0.21 & 2.04 & 0.03 & 0.34 & 0.05 & 0.02 & 37.0 & 7.5 & 3.1 & 10.1 \\
\hline Samples & $\mathrm{Sr} / \mathrm{Al}$ & $\mathrm{V} / \mathrm{Al}$ & $\mathrm{Cr} / \mathrm{Al}$ & $\mathrm{Co} / \mathrm{Al}$ & $\mathrm{Zr} / \mathrm{Al}$ & $\mathrm{Mo} / \mathrm{Al}$ & $\mathrm{U} / \mathrm{Al}$ & $\mathrm{Th} / \mathrm{Al}$ & $\mathrm{Cd} / \mathrm{Al}$ & $\mathrm{As} / \mathrm{Al}$ & $\mathrm{Sb} / \mathrm{Al}$ & $\mathrm{Ge} / \mathrm{Al}$ & $\mathrm{Pb} / \mathrm{Al}$ \\
\hline & ppm:\% & ppm:\% & ppm:\% & ppm:\% & $\mathrm{ppm}=\%$ & $\mathrm{ppm}: \%$ & ppm:\% & ppm: & ppm: $\%$ & ppm:\% & $\mathrm{ppm}: \%$ & $\mathrm{ppm}: \%$ & ppm:\% \\
\hline N1 & 137.1 & 14.2 & 17.8 & 1.4 & 161.1 & 0.7 & 1.5 & 2.5 & 0.1 & 4.3 & 0.2 & 0.4 & 3.1 \\
\hline N2 & 107.3 & 14.7 & 14.6 & 1.5 & 95.6 & 0.6 & 0.8 & 2.0 & 0.2 & 3.9 & 0.1 & 0.3 & 3.1 \\
\hline N3 & 27.2 & 13.3 & 13.4 & 1.3 & 20.4 & 0.5 & 0.4 & 1.2 & 0.0 & 1.1 & 0.1 & 0.2 & 22 \\
\hline N4 & 28.7 & 13.4 & 15.1 & 1.4 & 30.6 & 0.3 & 0.4 & 1.5 & 0.0 & 1.2 & 0.1 & 0.2 & 2.3 \\
\hline N5 & 34.8 & 13.4 & 15.8 & 1.4 & 40.5 & 0.6 & 0.5 & 1.6 & 0.1 & 1.5 & 0.1 & 0.2 & 24 \\
\hline NN1 & 64.3 & 13.3 & 19.2 & 1.4 & 128.9 & 0.1 & 0.5 & 1.6 & 0.0 & 1.0 & 0.1 & 0.5 & 27 \\
\hline NN2 & \#\#\# & 17.2 & 20.3 & 1.6 & 93.2 & 1.5 & 0.9 & 1.9 & $<$ LD. & 2.5 & $<$ LD. & 0.6 & 3.8 \\
\hline NN3 & 24.6 & 14.7 & 15.1 & 1.3 & 23.0 & 0.7 & 0.8 & 1.4 & 0.0 & 1.3 & 0.1 & 0.2 & 27 \\
\hline $\mathrm{CC} 1$ & 41.4 & 14.1 & 14.7 & 1.4 & 31.2 & 0.4 & 0.4 & 1.5 & 0.1 & 1.2 & 0.1 & 0.2 & 4.3 \\
\hline $\mathrm{CC} 2$ & 54.3 & 14.0 & 14.4 & 1.5 & 26.5 & 0.4 & 0.4 & 1.5 & 0.1 & 1.5 & 0.1 & 0.2 & 28 \\
\hline $\mathrm{CC} 3$ & 38.6 & 12.9 & 13.4 & 1.2 & 23.6 & 0.6 & 0.4 & 1.4 & 0.1 & 1.2 & 0.1 & 0.2 & 3.6 \\
\hline CC 4 & 83.1 & 13.6 & 14.7 & 1.6 & 31.4 & 0.6 & 0.4 & 1.5 & 0.1 & 1.8 & 0.1 & 0.2 & 3.2 \\
\hline CC 5 & 66.6 & 13.2 & 13.5 & 1.7 & 21.8 & 0.3 & 0.4 & 1.4 & 0.1 & 1.4 & 0.1 & 0.2 & 27 \\
\hline CC 6 & 50.1 & 13.7 & 14.7 & 1.5 & 29.6 & 0.4 & 0.4 & 1.5 & 0.1 & 1.4 & 0.1 & 0.2 & 27 \\
\hline CC 7 & 61.5 & 14.0 & 15.4 & 1.6 & 32.1 & 0.5 & 0.4 & 1.5 & 0.1 & 1.6 & 0.1 & 0.2 & 3.1 \\
\hline CC 8 & 57.3 & 14.4 & 14.8 & 1.6 & 29.4 & 0.3 & 0.4 & 1.5 & 0.0 & 1.7 & 0.1 & 0.2 & 29 \\
\hline CC 9 & 91.6 & 14.8 & 15.5 & 2.2 & 27.0 & 0.3 & 0.4 & 1.5 & 0.0 & 1.6 & 0.1 & 0.2 & 4.2 \\
\hline CC 10 & 74.5 & 14.3 & 14.6 & 1.8 & 25.6 & 0.4 & 0.4 & 1.4 & 0.0 & 1.5 & 0.1 & 0.2 & 27 \\
\hline CC 11 & 64.8 & 14.2 & 15.1 & 1.7 & 26.9 & 0.2 & 0.4 & 1.4 & 0.0 & 1.5 & 0.1 & 0.2 & 3.8 \\
\hline $\mathrm{CC} 12$ & 51.7 & 14.5 & 15.4 & 1.4 & 32.2 & 0.3 & 0.4 & 1.6 & 0.0 & 1.5 & 0.1 & 0.2 & 29 \\
\hline $\mathrm{CC} 13$ & 52.3 & 13.4 & 15.6 & 1.4 & 43.8 & 0.3 & 0.5 & 1.7 & 0.0 & 1.5 & 0.1 & 0.2 & 3.1 \\
\hline CC 14 & 63.1 & 13.7 & 15.2 & 1.5 & 34.3 & 0.3 & 0.4 & 1.5 & 0.0 & 1.5 & 0.1 & 0.2 & 28 \\
\hline Samples & As EF & & & GrEF & CuEF & Mo EF & $\mathrm{Ni} E \mathrm{~F}$ & & & UEF & VEF & $\mathrm{Zn} E \mathrm{~F}$ & $\mathrm{ZrEF}$ \\
\hline N1 & 228 & 0 & & 1.7 & 0.8 & 39 & 1.1 & & & 4.3 & 1.1 & 0.0 & 6.8 \\
\hline N2 & 20.8 & 0 & & 1.4 & 0.8 & 3.1 & 1.1 & & & 2.2 & 1.1 & 1.7 & 4.0 \\
\hline N3 & 6.0 & 0 & & 1.3 & 1.0 & 2.4 & 1.2 & & & 1.1 & 1.0 & 0.9 & 0.9 \\
\hline N4 & 6.6 & 0 & & 1.5 & 0.9 & 1.7 & 1.4 & & & 1.3 & 1.0 & 1.0 & 1.3 \\
\hline N5 & 8.0 & 0 & & 1.5 & 1.1 & 3.2 & 1.4 & & & 1.4 & 1.0 & 1.2 & 1.7 \\
\hline NN1 & 5.1 & 0 & & 1.9 & 0.6 & 0.8 & 0.6 & & & 1.4 & 1.0 & 1.0 & 5.5 \\
\hline NN2 & 13.2 & 0 & & 20 & 0.0 & 7.9 & 1.2 & & & 26 & 1.3 & 0.0 & 3.9 \\
\hline NN3 & 6.7 & 0 & & 1.5 & 1.3 & 3.9 & 1.6 & & & 2.3 & 1.1 & 1.0 & 1.0 \\
\hline $\mathrm{CC} 1$ & 6.7 & 0 & & 1.4 & 1.1 & 2.1 & 1.4 & & & 1.2 & 1.1 & 1.1 & 1.3 \\
\hline $\mathrm{CC2}$ & 7.8 & 0 & & 1.4 & 1.1 & 2.0 & 1.5 & & & 1.1 & 1.1 & 1.1 & 1.1 \\
\hline $\mathrm{CC} 3$ & 6.3 & 0 & & 1.3 & 1.1 & 3.3 & 1.3 & & & 1.1 & 1.0 & 0.9 & 1.0 \\
\hline CC 4 & 9.5 & 0 & & 1.4 & 1.1 & 3.4 & 1.5 & & & 1.2 & 1.0 & 1.4 & 1.3 \\
\hline CC 5 & 7.7 & 0 & & 1.3 & 0.9 & 1.4 & 1.3 & & & 1.0 & 1.0 & 1.8 & 0.9 \\
\hline CC 6 & 7.5 & 0 & & 1.4 & 1.1 & 2.4 & 1.4 & & & 1.2 & 1.0 & 1.2 & 1.3 \\
\hline CC7 & 8.6 & 0 & & 1.5 & 1.2 & 2.9 & 1.6 & & & 1.2 & 1.1 & 2.1 & 1.4 \\
\hline CC 8 & 9.0 & 0 & & 1.4 & 1.1 & 1.7 & 1.5 & & & 1.1 & 1.1 & 1.5 & 1.2 \\
\hline CC 9 & 8.4 & 1 & & 1.5 & 1.2 & 1.8 & 1.6 & & & 1.1 & 1.1 & 1.2 & 1.1 \\
\hline $\mathrm{CC} 10$ & 8.1 & 0 & & 1.4 & 1.1 & 2.0 & 1.5 & & & 1.1 & 1.1 & 1.0 & 1.1 \\
\hline CC 11 & 8.0 & 0 & & 1.5 & 1.0 & 1.3 & 1.3 & & & 1.1 & 1.1 & 1.1 & 1.1 \\
\hline $\mathrm{CC} 12$ & 7.9 & 0 & & 1.5 & 1.1 & 1.8 & 1.4 & & & 1.2 & 1.1 & 1.2 & 1.4 \\
\hline $\mathrm{CC} 13$ & 8.2 & 0 & & 1.5 & 1.0 & 1.6 & 1.3 & & & 1.3 & 1.0 & 1.3 & 1.9 \\
\hline CC 14 & 8.1 & 0 & & 1.5 & 1.0 & 1.6 & 1.4 & & & 1.2 & 1.0 & 1.1 & 1.5 \\
\hline
\end{tabular}


Table 6

Coefficient of determination $\mathrm{R}^{2}$ for the Element-A12O3 relationships.

\begin{tabular}{ll}
\hline $\begin{array}{l}\text { Element vs. } \mathrm{Al}_{2} \mathrm{O}_{3} \\
\text { correlation }\end{array}$ & $\begin{array}{l}\text { Determination } \\
\text { coeffidient } \mathrm{R}^{2}\end{array}$ \\
\hline $\mathrm{As}$ & 0.04 \\
$\mathrm{Cr}$ & 0.74 \\
$\mathrm{Cu}$ & 0.66 \\
$\mathrm{Ge}$ & 0.74 \\
$\mathrm{Mo}$ & 0.17 \\
$\mathrm{Ni}$ & 0.55 \\
$\mathrm{Sb}$ & 0.23 \\
$\mathrm{Th}$ & 0.78 \\
$\mathrm{U}$ & 0.68 \\
$\mathrm{~V}$ & 0.83 \\
$\mathrm{Zn}$ & 0.02 \\
$\mathrm{Zr}$ & 0.05 \\
\hline
\end{tabular}

Table 7

Comparison of the coefficient of determination $\mathrm{R}^{2}$ calculated for the two formations studied.

\begin{tabular}{|c|c|c|}
\hline & \multicolumn{2}{|c|}{ Determination coefficient $\mathrm{R}^{2}$} \\
\hline & Bancs Jumeaux Fm. & Argiles de Châtillon Fm. \\
\hline Fe vs. Al & 0.62 & $\begin{array}{l}\text { Sample set } 1: 0.62 \\
\text { Sample set } 2: 0.72\end{array}$ \\
\hline Pvs. As & 0.62 & 0.28 \\
\hline Pvs. As-EF & 0.90 & 0.07 \\
\hline Pvs. SB-EF & 0.90 & 0.04 \\
\hline Pvs. TOC & 0.05 & 0.46 \\
\hline Pvs. $\mathrm{Fe}_{\mathrm{xs}}$ & 0.79 & 0.08 \\
\hline $\mathrm{Fe}_{\mathrm{xs}}$ vs. Mo & 0.73 & 0.04 \\
\hline $\mathrm{Fe}_{\mathrm{ss}}$ vs. Mo-EF & 0.57 & 0.05 \\
\hline $\mathrm{Fe}_{\mathrm{ses}}$ vs. As & 0.72 & 0.03 \\
\hline $\mathrm{Fe}_{\mathrm{ss}}$ vs. As-EF & 0.57 & 0.32 \\
\hline $\mathrm{Fe}_{\mathrm{ses}} \mathrm{vs} . \mathrm{Sb}$ & 0.40 & 0.11 \\
\hline $\mathrm{Fe}_{\mathrm{ses}}$ vs. Sb-EF & 0.58 & 0.17 \\
\hline Mo-EF vs. As-EF & 0.87 & 0.19 \\
\hline
\end{tabular}




\section{Table 8}

Comparison of the depositional conditions of the two formations studied.

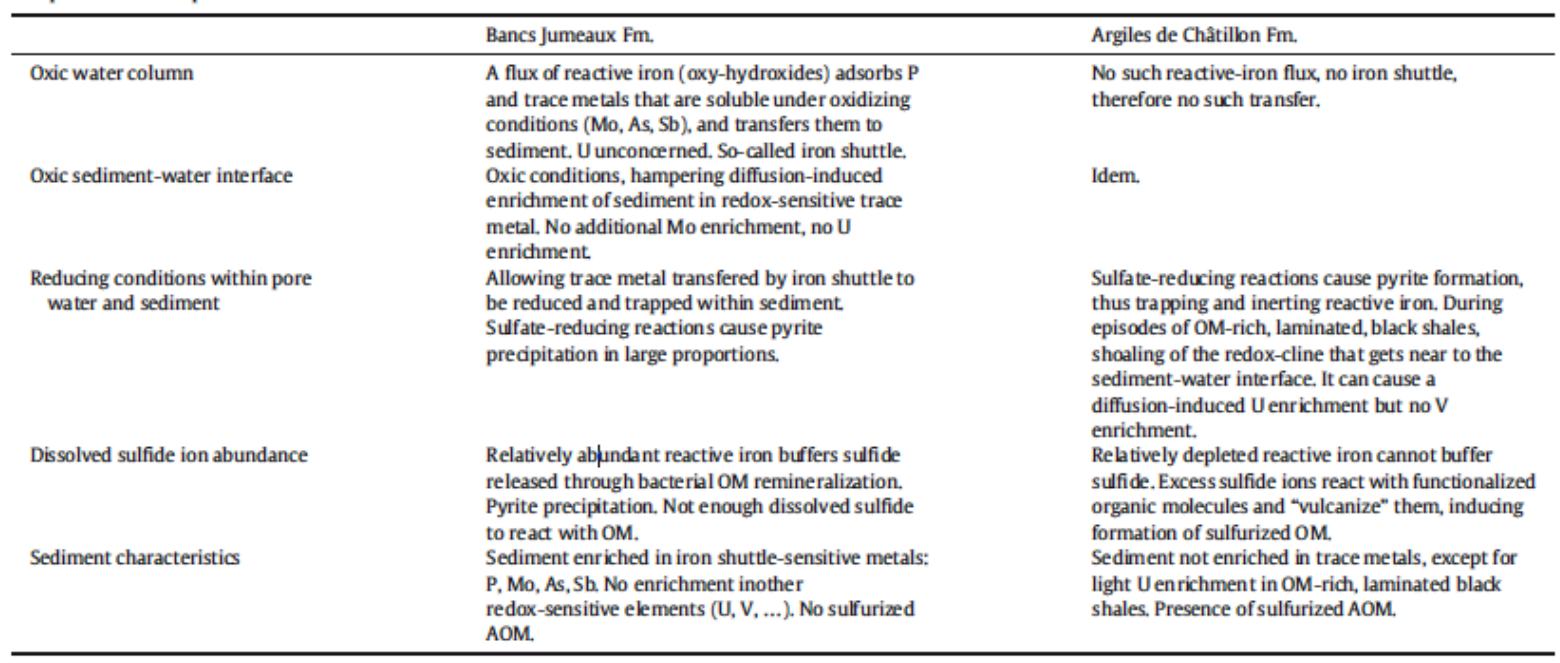

